\title{
Responses of soil microbial communities to freeze-thaw cycles in a Chinese temperate forest
}

Changpeng Sang ${ }^{1,2}$, Zongwei Xia ${ }^{1,3^{*}}$, Lifei Sun ${ }^{1}$, Hao Sun ${ }^{1}$, Ping Jiang ${ }^{1}$, Chao Wang ${ }^{1 *}$ and Edith Bai ${ }^{4,5}$

\begin{abstract}
Background: Freeze-thaw events are common in boreal and temperate forest ecosystems and are increasingly influenced by climate warming. Soil microorganisms play an important role in maintaining ecosystem stability, but their responses to freeze-thaw cycles (FTCS) are poorly understood. We conducted a field freeze-thaw experiment in a natural Korean pine and broadleaf mixed forest in the Changbai Mountain Nature Reserve, China, to determine the dynamic responses of soil microbial communities to FTCs.
\end{abstract}

Results: Bacteria were more sensitive than fungi to FTCs. Fungal biomass, diversity and community composition were not significantly affected by freeze-thaw regardless of the stage. Moderate initial freeze-thaw resulted in increased bacterial biomass, diversity, and copiotrophic taxa abundance. Subsequent FTCs reduced the bacterial biomass and diversity. Compared with the initial FTC, subsequent FTCs exerted an opposite effect on the direction of change in the composition and function of the bacterial community. Soil water content, dissolved organic carbon, ammonium nitrogen, and total dissolved phosphorus were important factors determining bacterial community diversity and composition during FTCs. Moreover, the functional potentials of the microbial community involved in $\mathrm{C}$ and $\mathrm{N}$ cycling were also affected by FTCs.

Conclusions: Different stages of FTCs have different ecological effects on the soil environment and microbial activities. Soil FTCs changed the soil nutrients and water availability and then mainly influenced bacterial community composition, diversity, and functional potentials, which may disturb $\mathrm{C}$ and $\mathrm{N}$ states in this temperate forest soil. This study also improves our understanding of microbial communities regulating their ecological functions in response to climate change.

Keywords: Freeze-thaw cycle, Microbial diversity, Microbial community composition, Soil resource availability, Functional potential

\section{Introduction}

Freeze-thaw fluctuations in soil temperature are common in some temperate, high-latitude, and high-altitude ecosystems (Grogan et al. 2004). Reduced snow cover in winter under climate warming conditions may lead to

\footnotetext{
*Correspondence: xiazongwei@iae.ac.cn; cwang@iae.ac.cn

${ }^{1}$ CAS Key Laboratory of Forest Ecology and Management, Institute of Applied Ecology, Chinese Academy of Sciences, Shenyang 110016, China

Full list of author information is available at the end of the article
}

increases in the frequency, severity, and spatial extent of soil freeze-thaw events (Fitzhugh et al. 2001). Some perturbations in freeze-thaw cycles (FTCs) may strongly influence soil microbial community composition and function (Haei et al. 2011). Recent research reminds us to pay attention to the responses of microorganisms to climate change (Cavicchioli et al. 2019) because microorganisms play an important role in maintaining ecosystem stability under changing climatic conditions (Jansson and Hofmockel 2020). We currently lack a deep and comprehensive understanding of microbial community 
responses to FTCs in temperate forest ecosystems, which is needed to efficiently forecast their ecological function changes under climate change scenarios.

The three known primary regulators of soil microbial activity, namely temperature, moisture, and substrate availability, are all strongly influenced by FTCs (Feng et al. 2007; Yergeau and Kowalchuk 2008; Ren et al. 2018). These primary regulators are low in frozen soil (Sorensen et al. 2018), and microorganisms subjected to these restrictions remain in a state of low activity or dormancy (Schimel and Mikan 2005; Mooshammer et al. 2017). When frozen soil thaws, these regulators increase, with a corresponding exponential increase in microbial activity (Larsen et al. 2002; Mikan et al. 2002). In addition, soil freezing and thawing reportedly kill and lyse certain microbial cells (Song et al. 2017), damage fine roots (Campbell et al. 2014), crush plant litter (Su et al. 2010), and destroy soil aggregates (Kvaernø and Øygarden 2006), all of which potentially release nutrient substrates that can be utilized by living microorganisms (Koponen et al. 2006). However, there is no definitive conclusion on whether there are changes in community composition and adjustment in the metabolic function of microorganisms surviving the FTCs, and what are the influencing factors. Therefore, further research is needed to enrich our understanding of the effect of freeze-thawing on soil microbial communities.

Numerous previous studies on FTCs have focused on the effects of moisture (Vimercati et al. 2020), temperature (Ernakovich and Wallenstein 2015; de Scally et al. 2016), freeze-thaw intensity (Perez-Mon et al. 2020), and nutrient availability (Sjursen et al. 2005; Chen et al. 2021) on microbial community composition. Firstly, high bacterial abundance and metabolic activity are supported by high water availability when soil thaws (Monteux et al. 2018); fungal communities are better adapted to the relative drought during the frozen period (Guhr et al. 2015). However, Yang et al. (2020) observed that excessive water could reduce oxygen supply, resulting in a decreased abundance of aerobic bacteria. George et al. (2021) have reported no significant correlation between water content and microbial community composition or diversity. Secondly, low temperature was found to be harsh stress that reduced microbial biomass (Jefferies et al. 2010), resulting in sharp decreases in species diversity and activity (Ade et al. 2018; Tikhonova et al. 2020). Generally, both amplitude and frequency are important aspects of freeze-thaw intensity, Jiang et al. (2018) have reported that a small freeze-thaw amplitude implies less damage to microbial communities and that freezing temperatures could explain a larger percentage of the variation in microbial community structure than thawing temperatures. Conversely, de Scally et al. (2016) have shown that temperature alone does not affect bacterial abundance. Liu et al. (2020) have observed that the number of FTCs has a greater effect on microbial community composition and function than the frequency of FTCs. Last but not least, nutrient availability plays a bottom-up role in controlling microbial community characteristics. High microbial abundance and diversity are accompanied by high resource availability (Cline et al. 2018), suggesting that the expansion of different resource niches facilitates the cohabitation of different microorganisms in the same location by supplying diverse substrates (Goldfarb et al. 2011). Moreover, the trade-off between the copiotrophic and oligotrophic groups in community composition would be disrupted in resource-rich freeze-thaw soil, causing domination by the copiotrophic group (Fierer et al. 2007). Taken together, these studies indicate that FTCs affect microbial communities in several ways, but a unified understanding of the factors that play the most important roles has not yet been developed. Different results may be obtained from different ecological types, soil backgrounds, freeze-thaw histories, and freezethaw stages, which need to be analyzed and discussed for specific objectives.

Most researches on FTCs are mainly conducted in laboratory simulations (Song et al. 2017), a benefit of which is that indoor incubation experiments can accurately control the freeze-thaw pattern. However, laboratory simulation experiments poorly reproduce the realistic environmental conditions of in situ experiments and frequently lead to results that may differ from actual field observations. Moreover, the effects of different stages of FTCs on the microbial community are likely to differ owing to differences in freeze-thaw intensity and microbial heterogeneity concerning their capacity to survive FTCs (Herrmann and Witter 2002). Furthermore, microbial communities in different soil horizons may have distinct responses to FTCs, depending on the soil characteristics and nutrient availability (Agnelli et al. 2004). To investigate the effects of FTCs on microbial dynamics in the field, we conducted an in situ freeze-thaw experiment in a temperate forest in northeastern China. Our objectives were to: (1) explore the dynamics of soil nutrient pools during FTCs; (2) clarify the changes in microbial community diversity, structure, and function potential at different FTCs stages; and (3) determine the primary factors driving the changes in microbial community diversity, structure, and function potential in relation to FTC processes. Results of the current study could help us unravel the dynamics of soil nutrients and microbial communities during FTCs, better predict the responses of soil microbial communities to environmental changes, and improve our understanding of ecosystem integrity in relation to climate change. 


\section{Materials and methods \\ Site description}

The study site was located in the Changbai Mountain National Nature Reserve in northeastern China $\left(42^{\circ} 24^{\prime}\right.$ $\left.06^{\prime \prime} \mathrm{N}, 128^{\circ} 05^{\prime} 59^{\prime \prime} \mathrm{E}\right)$. This region has a temperate continental monsoon climate with short warm summers and long cold winters. The climatic records from a weather station near the study site show that the mean annual air temperature is $3.6^{\circ} \mathrm{C}$, and January is the coldest month (average $-13.2{ }^{\circ} \mathrm{C}$ ). The mean annual precipitation is $745 \mathrm{~mm}$, approximately $13 \%$ of which is deposited on the ground as a solid phase of snow this winter. The average annual snow cover time is more than 110 days, and the maximum snow cover depth can reach $40 \mathrm{~cm}$. The zonal soil type in this region is dark brown soil developed from volcanic ash, and the soil texture is clay loam. The main forest community type is natural Korean pine and broadleaf mixed forest, and the predominant coniferous species is Pinus koraiensis, and the broad-leaved species are Tilia amurensis, Acer pseudosieboldianum, and Corylus mandshurica.

\section{Experimental design and sample collection}

In October 2017, five $3 \times 3 \mathrm{~m}$ plots were established in the broad-leaved Korean pine mixed forest in the nature reserve. The plots were located more than $5 \mathrm{~m}$ apart. Two button thermometers (DS1922L-F5\#, Maxim, USA) were embedded in each plot to continuously monitor the soil temperature at soil depths of 5 and $10 \mathrm{~cm}$. A third thermometer was installed in the shade approximately $1 \mathrm{~m}$ above the ground to detect air temperature changes. We started the soil sample collection on March 12, 2018, once the mean daily air temperature exceeded $0{ }^{\circ} \mathrm{C}$ for several consecutive days and the snow began to melt, but the soil was still frozen. To avoid missing the node of the first soil FTC and to accurately track the FTCs, sampling was conducted every 3 to 5 days from March 12; eight samplings (a-h) were performed until April 12 (Fig. 1a).

Based on the soil temperature curve during the eight samplings, we defined three pivotal nodes of the FTCs (a, d, and h), corresponding to stages I, II, and III in our study. Stage I represented Before FTC, meaning still frozen, and was treated as a control in the experiment; stage II indicated Initial FTC, meaning the first FTC observed during our study; and stage III represented Later FTC, meaning the last FTC observed during our study. One FTC is considered to have occurred once the soil temperature changed from below zero to above zero. Thus, a total of six FTCs in the O horizon $(0-5 \mathrm{~cm})$ and ten FTCs in the A horizon $(5-10 \mathrm{~cm})$ were confirmed during our observation period (Fig. 1a). In addition, three large snowfall events were monitored: the first on March 15, with $7.6 \mathrm{~mm}$ of precipitation; the second from April 5 to
6, with $10.7 \mathrm{~mm}$ of precipitation; and the third, a mixture of snow and rain from April 10 to 11, with $15.7 \mathrm{~mm}$ of precipitation (Fig. 1a). To avoid destroying the periodic integrity of the FTC in the soil samples, the sampling time was set after 3:00 p.m., when the soil temperature reached its peak during the day and was therefore considered to fall in the time interval between two adjacent FTCs. Six cylindrical soil cores $(5 \mathrm{~cm}$ in diameter and $5 \mathrm{~cm}$ in height) were collected from both the $\mathrm{O}$ horizon and A horizon after removing the snow and litter from each plot. The soil samples were then mixed to produce a composite soil sample for the $\mathrm{O}$ and A horizons. Snow and litter were backfilled after sampling. All samples were transported to a laboratory under low-temperature conditions $\left(4{ }^{\circ} \mathrm{C}\right)$.

\section{Basic properties of soil and runoff water}

The aggregate classification was executed by wet sieving the air-dried soil through three successive sieves $(2 \mathrm{~mm}$, $0.25 \mathrm{~mm}$, and $0.053 \mathrm{~mm}$ ) to divide the soil into four fractions (large macroaggregate, small macroaggregate, microaggregate, and silt or clay) (Elliott 1986). The soil samples for chemical and microbiological analyses were thoroughly homogenized and passed through a 2-mm sieve after removing pebbles and plant residue before further treatment. Soil $\mathrm{pH}$ was measured at a ratio of dry soil to water ratio of 1:2.5 (w:v) (Bünemann et al. 2012) using a $\mathrm{pH}$ meter (Leici, Shanghai, China). Soil water content (SWC) was determined by oven-drying the fresh soil. Soil organic carbon (SOC) and total nitrogen (TN) were determined using an elemental analyzer (Vario MACRO cube, Elementar, Hanau, Germany). Soil total phosphorus (TP) was extracted through sulfuric acid and perchloric acid digestion (Scott and Condron 2003). Soil available phosphorus (AP) was extracted according to the method described by Olsen-P (Olsen et al. 1954). Soil microbial biomass carbon (MBC), nitrogen (MBN), and phosphorus (MBP) were extracted in fresh soil via chloroform fumigation extraction (Brookes et al. 1982, 1985; Joergensen 1996). Dissolved organic C (DOC), total dissolved N (TDN), and total dissolved P (TDP) were extracted directly from non-fumigated soil. $\mathrm{C}$ and $\mathrm{N}$ contents in the extract were measured using a total organic $\mathrm{C}$ analyzer (fitted with a TN unit) (TOC-L CPH, Shimadzu, Tokyo, Japan), and $\mathrm{P}$ content in the extract was determined by the ascorbic acid molybdenum-antimony colorimetric method (Murphy and Riley 1962) and using an automated discrete analyzer (SmartChem140, AMS, Rome, Italy). Soil ammonium nitrogen $\left(\mathrm{NH}_{4}{ }^{+}-\mathrm{N}\right)$ and nitrate nitrogen $\left(\mathrm{NO}_{3}{ }^{-}-\mathrm{N}\right)$ were extracted using $2 \mathrm{M}$ potassium chloride at a soil:solution ratio of 1:5 (Zhou et al. 2011), and their concentrations were measured using the automated discrete analyzer. Dissolved C, N, 

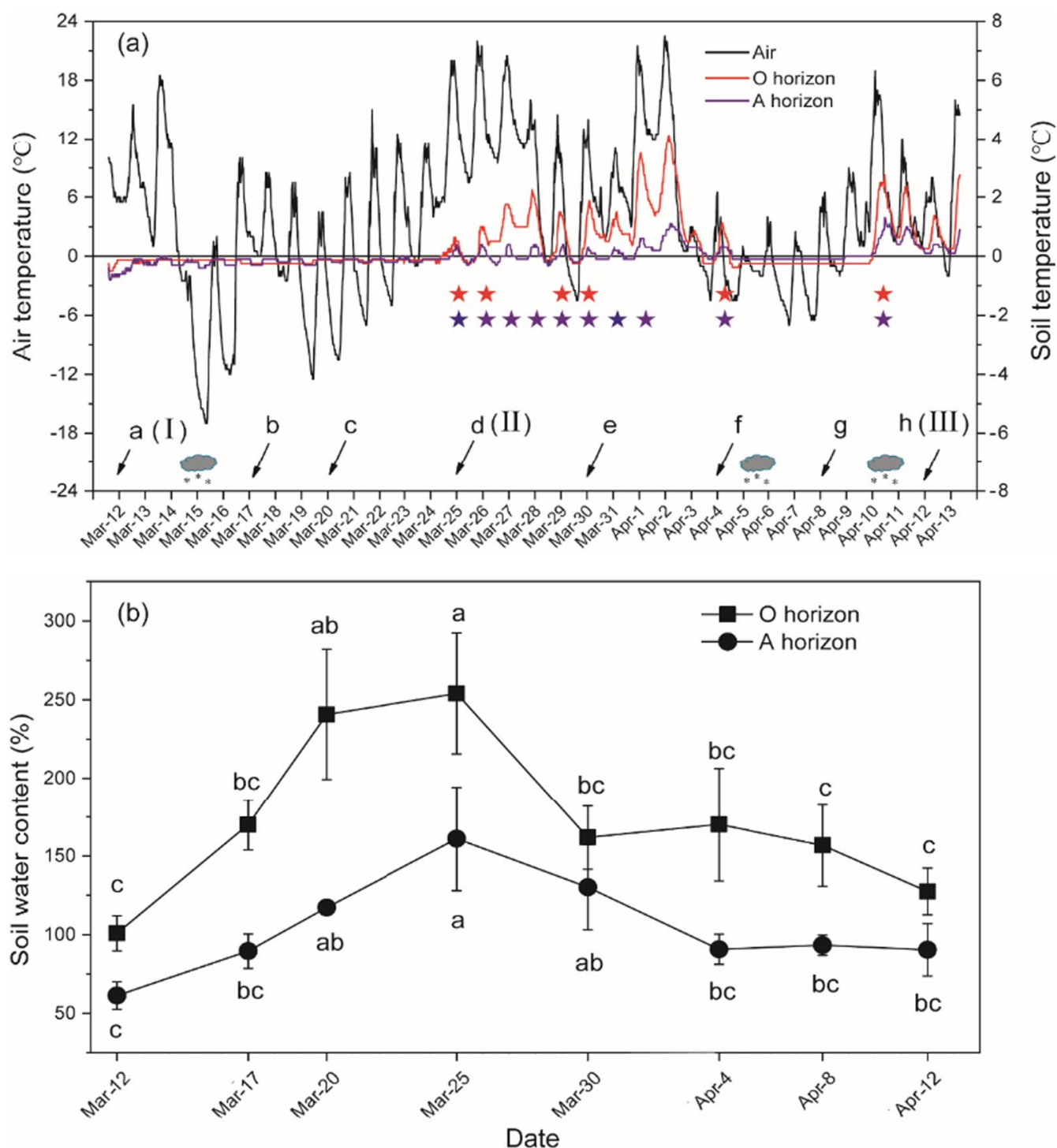

Fig. 1 The variations of $\mathbf{a}$ air and soil temperature and $\mathbf{b}$ soil water content in the experimental site during the study period. Lowercase letters (a-h) and arrows along the timeline in figure $\mathbf{a}$ indicate the sampling time. Mar 12, Mar 25, and Apr 12 are three pivotal time for our study, which are called stage I, II, and III for short. The asterisks are used to label the date of the freeze-thaw cycles were detected in O horizon (red) and A horizon (blue) soil. Three snowfall events were recorded during the period indicated by the snowfall symbol. Lowercase letters in figure $\mathbf{b}$ indicate significant differences in soil water content among different sampling time for each soil layer $(P<0.05)$

and $\mathrm{P}$ contents in runoff water were determined in the same manner as for the soil extraction described above.

\section{Extracellular enzyme activity assay}

The activities of soil $\beta$-glucosidase (BG, catalyzing the terminal reaction in cellulose degradation), $\mathrm{N}$-acetylglucosaminidase (NAG, catalyzing the terminal reaction in chitin degradation), and acid phosphatase (ACP, mineralizing organic $\mathrm{P}$ from phospholipids and phosphosaccharides) (Sinsabaugh et al. 2009; Waring et al.
2014) were measured using fluorometric assays according to the protocol of Saiya-Cork et al. (2002) with modifications by Allison et al. (2009) and German et al. (2011). The dispensing of buffer, sample, reference, and substrates followed a strict order and position on the well plate (Deforest 2009). Fluorescence was detected using a multi-functional microplate tester (Synergy H1M, Bio-Tek, Winooski, USA) with $365 \mathrm{~nm}$ excitation and $450 \mathrm{~nm}$ emission filters after terminating the reaction using $1.0 \mathrm{M}$ sodium hydroxide solution. The activity of these enzymes, expressed as the rate of product 
formation $\left(\mathrm{nmol} \cdot \mathrm{h}^{-1} \cdot \mathrm{g}^{-1}\right)$, was calculated as previously described (German et al. 2011).

\section{Quantitative PCR (qPCR) and amplicon sequencing}

DNA was extracted from $0.25 \mathrm{~g}$ freeze-dried soil using the DNeasy PowerSoil Kit (Qiagen, Hilden, Germany) according to the manufacturer's protocols. The extracted DNA was preliminarily assessed using a Nanodrop spectrophotometer (Thermo Fisher Scientific, Waltham, USA). The qPCR of bacterial $16 \mathrm{~S}$ rRNA genes and fungal internal transcribed spacers (ITS) was conducted using the primer sets 341F/518R (341F: 5'-CCT ACG GGA GGC AGC AG-3' and 518R: $5^{\prime}$-ATT ACC GCG GCT GCT GG-3') (Muyzer et al. 1993) and ITS1F/ITS2R (ITS1F: 5'-CTT GGT CAT TTA GAG GAA GTA A-3' and ITS2R: 5'-GCT GCG TTC TTC ATC GAT GC-3') (Buée et al. 2009) and a LightCycler ${ }^{\circledR} 96$ Real-Time PCR System (Roche, Mannheim, Germany) to quantify bacterial and fungal abundance. The $20 \mu \mathrm{L}$ amplification system contained $10 \mu \mathrm{L}$ of TB Green ${ }^{\circledR}$ Premix Ex Taq ${ }^{\text {TM }}(2 \times$; Tli RNaseH Plus) (Takara, Shiga, Japan), $0.8 \mu \mathrm{L}$ of each primer, $1 \mu \mathrm{L}$ of 1:10-diluted soil metagenomic DNA, and 7.4 $\mu \mathrm{L}$ of $\mathrm{dd}_{2} \mathrm{O}$. Forty amplification cycles were performed, and each cycle consisted of denaturation at $95^{\circ} \mathrm{C}$ for $5 \mathrm{~s}$, annealing at $55^{\circ} \mathrm{C}$ for $30 \mathrm{~s}$, and elongation at $72{ }^{\circ} \mathrm{C}$ for $30 \mathrm{~s}$.

To identify both bacterial and fungal communities in the samples, the primer sets 515F/806R (Caporaso et al. 2011) and ITS1F/ITS2 (Buée et al. 2009) targeting the $\mathrm{V} 4$ region of the bacterial $16 \mathrm{~S}$ rRNA gene and the ITS1 region of the fungal ITS gene were selected for PCR. Amplification of the target genes was performed in triplicate in a $25 \mu \mathrm{L}$ mixture, comprising $12.5 \mu \mathrm{L}$ of $2 \times$ Taq Plus Master Mix (Vazyme, Nanjing, China), 3.0 $\mu \mathrm{L}$ of bovine serum albumin (BSA, $2 \mathrm{ng} \cdot \mu \mathrm{L}^{-1}$ ), $1.0 \mu \mathrm{L}$ of $5-\mu \mathrm{M}$ of each primer, approximately $30 \mathrm{ng}$ of template DNA, and $\mathrm{dd}_{2} \mathrm{O}$ to make up the remaining volume. The PCR procedure for $16 \mathrm{~S}$ rRNA genes or ITS genes included denaturation at $94{ }^{\circ} \mathrm{C}$ for $5 \mathrm{~min}$, followed by 30 or 34 cycles of denaturation at $94{ }^{\circ} \mathrm{C}$ for $30 \mathrm{~s}$, annealing at 50 or $55{ }^{\circ} \mathrm{C}$ for $30 \mathrm{~s}$, elongation at $72{ }^{\circ} \mathrm{C}$ for $60 \mathrm{~s}$, and a final extension at $72{ }^{\circ} \mathrm{C}$ for $7 \mathrm{~min}$. The triplicate PCR amplicons for each sample were combined, confirmed, and purified successively, and the qualified library was sequenced on an Illumina Miseq platform (Illumina, San Diego, USA), producing 250-300 bp paired-end (PE) reads. The PE reads were merged using FLASH (v1.20), and chimeras were removed using the UCHIME method (Edgar et al. 2011) integrated into VSEARCH (v2.7.1). The quality-filtered sequences of $16 \mathrm{~S}$ rRNA and ITS gene amplicons were clustered into operational taxonomic units (OTUs) at a 97\% similarity cutoff using UPARSE (Edgar 2013). A total of 53,000 and 23,500 sequences were randomly subsampled to the minimum number for $16 \mathrm{~S}$ and ITS to rarify the data sets from each sample, respectively. Representative bacterial (OTU) sequences were classified taxonomically using the Ribosomal Database Project (RDP) (http://rdp.cme.msu.edu) classifier (Wang et al. 2007) based on the SILVA database (http://www. arb-silva.de) (Quast et al. 2013), and the taxonomy of fungal OTU sequences was assigned against the NCBI Basic Local Alignment Search Tool (BLAST). The richness and Shannon indices were calculated to assess microbial alpha diversity. To link the functional properties of microbial communities with the biogeochemical cycling process of elements, bacterial and fungal potential function categories were predicted based on the Functional Annotation of Prokaryotic Taxa (FAPROTAX) (Louca et al. 2016) and FUNGuild (Nguyen et al. 2016) databases, and only guilds with the confidence ranking of "highly probable" and "probable" were used for fungal functional group analysis.

\section{Statistical analyses}

Levene's test was used to check the homogeneity of variance, and logarithmic transformation was performed on the data, where required, before statistical analyses (Leff et al. 2012). The differences in soil physicochemical properties, species diversity, extracellular enzyme activity, and functional gene abundance among different FTC stages were evaluated using one-way ANOVA and LSD multiple comparison tests (Grogan et al. 2004). The differences between soil horizons were analyzed using $t$-tests. A two-way ANOVA was conducted on some variables to determine the main and interaction effects of FTC stages and soil horizons. Regression analysis was conducted to explore the response of microbial diversity to changes in water and nutrient availability, and the environmental factors influencing nutrient availability were also analyzed. The correlation between bacterial community composition and soil environmental variables was explored using the Mantel test with Pearson's correlation coefficient and 999 permutations. Constrained principal coordinate analysis (CPCoA) of bacterial and fungal OTUs was performed to determine the beta-diversity of the community at different stages (Zgadzaj et al. 2016). Soil environmental variables that strongly contributed to the change in bacterial and fungal community composition were identified by redundancy analysis (RDA) (de Scally et al. 2016). Statistical analyses were performed using SPSS 19.0 for Windows (SPSS, Inc., Chicago, USA), and statistical significance was defined at $P<0.05$. Figures are constructed using Origin 2018 (OriginLab, Northampton, USA) and Canoco 5.0 (Canoco5.com). 


\section{Results}

\section{Physicochemical properties of runoff water and soil}

Once the frozen soil thawed, a large amount of snowmelt water infiltrated the soil and instantly raised SWC, which remained high throughout the experiment (Table 1, Fig. 1b). We also found that higher SWC corresponded to higher soil nutrient content (Additional file 1: Fig. S1). As shown in Additional file 1: Fig. S2, DOC concentration in runoff water decreased continuously during the experiment and ultimately lowered by $63.3 \%$. Both TDP and $\mathrm{NH}_{4}{ }^{+}-\mathrm{N}$ in runoff water increased sharply during the first FTC (stage II) and then decreased considerably after several FTCs (stage III). The contents of TDN, dissolved organic $\mathrm{N}(\mathrm{DON})$, and $\mathrm{NO}_{3}{ }^{-}-\mathrm{N}$ in runoff water decreased during the early period but increased after April 4, which coincided with the sudden low-temperature period before sampling time point $f$ and the increased temperature and precipitation after it (Fig. 1a).

The FTCs did not change the soil pH, but significantly affected soil nutrient pools, especially the available active nutrients such as DOC, TDN, TDP, and $\mathrm{NH}_{4}{ }^{+}-\mathrm{N}$ (Table 1). The content of soil nutrients (DOC, TDN, DON, TDP, and $\mathrm{NH}_{4}{ }^{+}-\mathrm{N}$ ) reached the highest when the first FTC occurred and then decreased gradually with the process of freeze-thaw for both horizons. The content of $\mathrm{NO}_{3}{ }^{-}-\mathrm{N}$ first increased rapidly and then decreased gradually in A-horizon soil after the first FTC (Additional file 1: Fig. S3). Soil MBC responded significantly to FTCs and showed a slightly increasing trend at the first FTC (stage II), followed by a decline after several FTCs (stage III) (Table 2, Additional file 1: Fig. S4), consistent with the trend in variation of microbial biomass expressed by $16 \mathrm{~S}$ rRNA gene abundance (Table 2). By comparing the stoichiometric ratios of $\mathrm{C}, \mathrm{N}$, and $\mathrm{P}$ in each pool, we found that the SOC/TP and $\mathrm{TN} / \mathrm{TP}$ ratios increased significantly at stage II and then decreased at stage III in the A-horizon soil. The DOC/TDN ratio showed the lowest value whereas the TDN/TDP ratio had the highest value at stage II in the A-horizon soil (Table 1 ). The $\mathrm{MBC} / \mathrm{MBN}$ ratio decreased significantly after the first FTC, and the $\mathrm{MBC} / \mathrm{MBP}$ showed an initial sharp decrease at stage II, followed by recovery at stage III. The MBN/MBP ratio did not change at the early stage (II), but increased significantly after repeated FTCs (stage III) (Table 2).

The soil aggregate composition changed markedly under FTCs (Additional file 1: Fig. S5). The first FTC caused a portion of the macroaggregates $(>250 \mu \mathrm{m})$ to break into microaggregates $(53-250 \mu \mathrm{m})$ in the $\mathrm{O}$ horizon, whereas continuous FTCs led to changes in the soil aggregate composition-from microaggregates to clay particles-in the A horizon.

Table 1 Soil physicochemical properties in different freeze-thaw stages

\begin{tabular}{|c|c|c|c|c|c|c|c|c|c|}
\hline \multirow[t]{2}{*}{ Variables } & \multicolumn{3}{|l|}{ O horizon soil } & \multicolumn{3}{|l|}{ A horizon soil } & \multicolumn{3}{|c|}{ Two-way ANOVA } \\
\hline & Stage I & Stage II & Stage III & Stage I & Stage II & Stage III & FTC & $\mathrm{H}$ & $\mathrm{FTC} \times \mathrm{H}$ \\
\hline $\mathrm{pH}$ value & $5.13 \pm 0.11$ & $5.50 \pm 0.17$ & $5.24 \pm 0.03$ & $4.99 \pm 0.08$ & $4.95 \pm 0.15$ & $5.13 \pm 0.05$ & n.s. & $* *$ & n.s. \\
\hline SWC (\%) & $100.8 \pm 11.1 \mathbf{b}$ & $254.0 \pm 38.4 \mathbf{a}$ & $127.4 \pm 14.9 \mathbf{b}$ & $61.3 \pm 8.8 \mathbf{b}$ & $161.1 \pm 33.1 \mathbf{a}$ & $90.3 \pm 16.6 \mathbf{b}$ & $* * *$ & $* *$ & n.s. \\
\hline $\mathrm{SOC}\left(\mathrm{g} \cdot \mathrm{kg}^{-1}\right)$ & $126.9 \pm 3.8 \mathbf{b}$ & $210.9 \pm 20.7 \mathbf{a}$ & $202.2 \pm 21.9 \mathbf{a}$ & $54.7 \pm 2.6 \mathbf{b}$ & $133.1 \pm 21.6 \mathbf{a}$ & $68.0 \pm 5.5 \mathbf{b}$ & $* * *$ & $* * *$ & $*$ \\
\hline $\mathrm{TN}\left(\mathrm{g} \cdot \mathrm{kg}^{-1}\right)$ & $9.4 \pm 0.4 \mathbf{b}$ & $15.3 \pm 1.2 \mathbf{a}$ & $14.4 \pm 1.1 \mathbf{a}$ & $4.3 \pm 0.2 \mathbf{b}$ & $10.5 \pm 1.4 \mathbf{a}$ & $5.9 \pm 0.5 \mathbf{b}$ & $* * *$ & $* * *$ & $*$ \\
\hline $\mathrm{TP}\left(\mathrm{g} \cdot \mathrm{kg}^{-1}\right)$ & $1.32 \pm 0.1$ & $1.4 \pm 0.1$ & $1.4 \pm 0.1$ & $1.0 \pm 0.1 \mathbf{b}$ & $1.4 \pm 0.1 \mathbf{a}$ & $1.1 \pm 0.1 \mathbf{a b}$ & n.s. & $* *$ & n.s. \\
\hline $\mathrm{SOC} / \mathrm{TN}$ & $13.5 \pm 0.4$ & $13.7 \pm 0.5$ & $13.9 \pm 0.6$ & $12.6 \pm 0.3$ & $12.4 \pm 0.6$ & $11.6 \pm 0.3$ & n.s. & $* * *$ & n.s. \\
\hline $\mathrm{SOC} / \mathrm{TP}$ & $97.4 \pm 5.8 \mathbf{b}$ & $148.4 \pm 16.0 \mathbf{a}$ & $147.6 \pm 16.9 \mathbf{a}$ & $56.0 \pm 6.4 \mathbf{b}$ & $97.0 \pm 13.2 \mathbf{a}$ & $63.2 \pm 3.5 \mathbf{b}$ & $* * *$ & $* * *$ & n.s. \\
\hline $\mathrm{TN} / \mathrm{TP}$ & $7.21 \pm 0.43 \mathbf{b}$ & $10.8 \pm 0.8 \mathbf{a}$ & $10.5 \pm 0.9 a$ & $4.4 \pm 0.5 \mathbf{b}$ & $7.7 \pm 0.7 \mathbf{a}$ & $5.5 \pm 0.3 \mathbf{b}$ & $* * *$ & $* * *$ & n.s. \\
\hline $\mathrm{DOC}\left(\mathrm{mg} \cdot \mathrm{kg}^{-1}\right)$ & $350.4 \pm 27.9 \mathbf{b}$ & $576.6 \pm 79.2 \mathbf{a}$ & $363.1 \pm 34.3 \mathbf{b}$ & $264.1 \pm 29.8 \mathbf{b}$ & $419.6 \pm 22.5 \mathbf{a}$ & $266.3 \pm 36.7 \mathbf{b}$ & ** & $* *$ & n.s. \\
\hline $\mathrm{TDN}\left(\mathrm{mg} \cdot \mathrm{kg}^{-1}\right)$ & $180.0 \pm 45.3 \mathbf{b}$ & $299.1 \pm 34.9 \mathbf{a}$ & $157.9 \pm 17.9 \mathbf{b}$ & $76.8 \pm 19.0 \mathbf{b}$ & $210.0 \pm 19.8 \mathbf{a}$ & $71.7 \pm 10.7 \mathbf{b}$ & $* * *$ & $* * *$ & n.s. \\
\hline $\mathrm{DON}\left(\mathrm{mg} \cdot \mathrm{kg}^{-1}\right)$ & $101.6 \pm 36.1 \mathbf{b}$ & $187.0 \pm 25.3 \mathbf{a}$ & $123.5 \pm 15.0 \mathbf{b}$ & $57.8 \pm 17.5 \mathbf{b}$ & $135.0 \pm 15.5 \mathbf{a}$ & $57.9 \pm 8.7 \mathbf{b}$ & ** & $* *$ & n.s. \\
\hline $\mathrm{NH}_{4}{ }^{+}-\mathrm{N}\left(\mathrm{mg} \cdot \mathrm{kg}^{-1}\right)$ & $53.8 \pm 10.2 \mathbf{b}$ & $98.9 \pm 11.5 \mathbf{a}$ & $25.1 \pm 2.5 c$ & $10.9 \pm 1.5 \mathbf{b}$ & $53.5 \pm 4.9 \mathbf{a}$ & $6.9 \pm 1.7 \mathbf{b}$ & $* * *$ & $* * *$ & * \\
\hline $\mathrm{NO}_{3}{ }^{-}-\mathrm{N}\left(\mathrm{mg} \cdot \mathrm{kg}^{-1}\right)$ & $24.5 \pm 5.5 a$ & $13.2 \pm 1.9 \mathbf{a b}$ & $9.3 \pm 2.1 \mathbf{b}$ & $8.0 \pm 0.8 \mathbf{b}$ & $21.5 \pm 4.6 \mathbf{a}$ & $6.9 \pm 0.8 \mathbf{b}$ & $* *$ & n.s & ** \\
\hline $\mathrm{TDP}\left(\mathrm{mg} \cdot \mathrm{kg}^{-1}\right)$ & $9.3 \pm 1.2 \mathbf{b}$ & $18.4 \pm 3.5 \mathbf{a}$ & $11.4 \pm 1.4 \mathbf{a b}$ & $4.3 \pm 0.6 \mathbf{b}$ & $8.5 \pm 0.9 \mathbf{a}$ & $4.2 \pm 0.5 \mathbf{b}$ & $* * *$ & $* * *$ & n.s. \\
\hline $\mathrm{AP}\left(\mathrm{mg} \cdot \mathrm{kg}^{-1}\right)$ & $15.3 \pm 2.1 \mathbf{b}$ & $23.6 \pm 3.9 \mathbf{a b}$ & $28.6 \pm 2.0 \mathbf{a}$ & $6.7 \pm 1.3 \mathbf{b}$ & $13.3 \pm 2.0 \mathbf{a}$ & $11.9 \pm 1.4 \mathbf{a}$ & ** & $* * *$ & n.s. \\
\hline DOC/TDN & $2.3 \pm 0.4$ & $1.9 \pm 0.17$ & $2.4 \pm 0.2$ & $3.8 \pm 0.5 \mathbf{a}$ & $2.1 \pm 0.2 \mathbf{b}$ & $3.8 \pm 0.3 \mathbf{a}$ & $* * *$ & $* * *$ & n.s. \\
\hline DOC/TDP & $40.4 \pm 6.4$ & $34.1 \pm 6.0$ & $32.9 \pm 3.1$ & $63.0 \pm 5.7$ & $52.1 \pm 7.8$ & $63.9 \pm 6.1$ & n.s. & $* * *$ & n.s. \\
\hline TDN/TDP & $19.7 \pm 4.6$ & $18.0 \pm 2.9$ & $14.1 \pm 1.3$ & $17.7 \pm 2.7 \mathbf{b}$ & $25.5 \pm 3.3 \mathbf{a}$ & $16.9 \pm 1.0 \mathbf{b}$ & n.s. & n.s. & n.s. \\
\hline
\end{tabular}

SWC soil water content, SOC soil organic $\mathrm{C}, T N$ total $\mathrm{N}, T P$ total $\mathrm{P}, D O C$ dissolved organic $\mathrm{C}, T D N$ total dissolved $\mathrm{N}, D O N$ dissolved organic $\mathrm{N}, \mathrm{NH}{ }_{4}^{+}-\mathrm{N}$ Ammonium $\mathrm{N}$, $\mathrm{NO}_{3}{ }^{-}-N$ Nitrate N, TDP total dissolved P, AP Available P, the same below. Data are displayed as means \pm standard errors $(n=5)$. The effects of the freeze-thaw cycle $(\mathrm{FTC})$, soil horizon $(\mathrm{H})$, and their interaction $(\mathrm{FTC} \times \mathrm{H})$ are shown at the right columns. Bold lowercase letters indicate significant differences among different stages within the same horizon $(P<0.05)$. Two-way ANOVA results $* P<0.05, * * P<0.01,{ }^{* * *} P<0.001$ and n.s. not significant 
Table 2 Soil microbial characteristics in different freeze-thaw stages

\begin{tabular}{|c|c|c|c|c|c|c|c|c|c|}
\hline \multirow[t]{2}{*}{ Variables } & \multicolumn{3}{|l|}{ O horizon soil } & \multicolumn{3}{|l|}{ A horizon soil } & \multicolumn{3}{|c|}{ Two-way ANOVA } \\
\hline & Stage I & Stage II & Stage III & Stage I & Stage II & Stage III & FTC & $\mathrm{H}$ & $\mathrm{FTC} \times \mathrm{H}$ \\
\hline $\mathrm{MBC}\left(\mathrm{mg} \cdot \mathrm{kg}^{-1}\right)$ & $3951.5 \pm 407.4 \mathbf{a b}$ & $4661.8 \pm 418.6 \mathbf{a}$ & $3322.2 \pm 395.8 \mathbf{b}$ & $1925.4 \pm 325.7 \mathbf{a b}$ & $2689.3 \pm 463.0 \mathbf{a}$ & $1493.3 \pm 289.6 \mathbf{b}$ & * & $* * *$ & n.s. \\
\hline $\mathrm{MBN}\left(\mathrm{mg} \cdot \mathrm{kg}^{-1}\right)$ & $462.7 \pm 60.7$ & $667.4 \pm 85.1$ & $467.9 \pm 78.0$ & $199.4 \pm 38.0 \mathbf{b}$ & $343.0 \pm 57.7 \mathbf{a}$ & $196.7 \pm 42.4 \mathbf{b}$ & $*$ & $* * *$ & n.s. \\
\hline $\operatorname{MBP}\left(\mathrm{mg} \cdot \mathrm{kg}^{-1}\right)$ & $86.6 \pm 12.6 \mathbf{b}$ & $127.5 \pm 6.3 \mathbf{a}$ & $57.2 \pm 5.5 c$ & $24.8 \pm 5.6 \mathbf{b}$ & $78.8 \pm 20.9 \mathbf{a}$ & $17.6 \pm 4.9 \mathbf{b}$ & $* * *$ & $* * *$ & n.s. \\
\hline $\mathrm{MBC} / \mathrm{MBN}$ & $8.7 \pm 0.4 \mathbf{a}$ & $7.2 \pm 0.4 \mathbf{b}$ & $7.4 \pm 0.5 \mathbf{b}$ & $9.8 \pm 0.2 \mathbf{a}$ & $7.8 \pm 0.2 \mathbf{b}$ & $8.2 \pm 0.8 \mathbf{b}$ & $* *$ & $*$ & n.s. \\
\hline $\mathrm{MBC} / \mathrm{MBP}$ & $47.4 \pm 4.1 \mathrm{ab}$ & $36.4 \pm 2.3 \mathbf{b}$ & $58.3 \pm 4.8 \mathbf{a}$ & $81.1 \pm 5.9 a$ & $39.1 \pm 5.0 \mathbf{b}$ & $93.4 \pm 15.9 \mathbf{a}$ & $* * *$ & $* * *$ & n.s. \\
\hline MBN/MBP & $5.4 \pm 0.3 \mathbf{b}$ & $5.2 \pm 0.5 \mathbf{b}$ & $8.1 \pm 1.0 \mathbf{a}$ & $8.3 \pm 0.6 \mathbf{a b}$ & $5.1 \pm 0.8 \mathbf{b}$ & $12.2 \pm 2.7 \mathbf{a}$ & ** & * & n.s. \\
\hline $\mathrm{BG}\left(\mathrm{nmol} \mathrm{h}^{-1} \mathrm{~g}^{-1}\right)$ & $42.7 \pm 9.9 \mathbf{b}$ & $63.5 \pm 4.6 \mathbf{a}$ & $30.8 \pm 2.2 \mathbf{b}$ & $12.1 \pm 3.4 \mathbf{b}$ & $29.2 \pm 4.7 \mathbf{a}$ & $14.1 \pm 4.0 \mathbf{b}$ & $* * *$ & $* * *$ & n.s. \\
\hline $\begin{array}{l}\text { NAG }(\mathrm{nmol} \\
\left.\mathrm{h}^{-1} \mathrm{~g}^{-1}\right)\end{array}$ & $12.7 \pm 3.1$ & $14.7 \pm 1.3$ & $8.9 \pm 1.3$ & $4.0 \pm 1.0 \mathbf{b}$ & $10.5 \pm 1.8 \mathbf{a}$ & $5.2 \pm 0.9 \mathbf{b}$ & $* *$ & $* * *$ & n.s. \\
\hline ACP $\left(n m o l h^{-1} g^{-1}\right)$ & $171.9 \pm 19.9 \mathbf{a b}$ & $212.4 \pm 17.9 \mathbf{a}$ & $149.8 \pm 11.1 \mathbf{b}$ & $97.0 \pm 17.2$ & $134.1 \pm 14.1$ & $98.2 \pm 15.1$ & * & $* * *$ & n.s. \\
\hline $\mathrm{BG} / \mathrm{NAG}$ & $3.5 \pm 0.4$ & $4.4 \pm 0.4$ & $3.7 \pm 0.5$ & $3.0 \pm 0.2$ & $3.0 \pm 0.5$ & $2.89 \pm 0.6$ & n.s. & $*$ & n.s. \\
\hline $\mathrm{BG} / \mathrm{ACP}$ & $0.24 \pm 0.03 \mathbf{a b}$ & $0.31 \pm 0.03 \mathbf{a}$ & $0.21 \pm 0.01 \mathbf{b}$ & $0.12 \pm 0.01 \mathbf{b}$ & $0.23 \pm 0.05 \mathbf{a}$ & $0.13 \pm 0.02 \mathbf{a b}$ & $* *$ & $* * *$ & n.s. \\
\hline $\mathrm{NAG/ACP}$ & $0.07 \pm 0.01$ & $0.07 \pm 0.00$ & $0.06 \pm 0.01$ & $0.04 \pm 0.00 \mathbf{b}$ & $0.08 \pm 0.01 \mathbf{a}$ & $0.05 \pm 0.01 \mathbf{a b}$ & n.s. & n.s. & $*$ \\
\hline $\begin{array}{l}\text { Bacteria biomass } \\
\left(\times 10^{8} \text { copies } \cdot g^{-1}\right)\end{array}$ & $482.9 \pm 60.7 \mathbf{b}$ & $655.1 \pm 24.4 \mathbf{a}$ & $393.8 \pm 58.6 \mathbf{b}$ & $526.3 \pm 25.3 \mathbf{a b}$ & $612.6 \pm 44.0 \mathbf{a}$ & $430.4 \pm 51.0 \mathbf{b}$ & $* * *$ & n.s. & n.s. \\
\hline $\begin{array}{l}\text { Fungi biomass } \\
\left(\times 10^{8} \text { copies } \cdot g^{-1}\right)\end{array}$ & $7.8 \pm 1.3$ & $8.4 \pm 2.9$ & $8.1 \pm 1.6$ & $8.6 \pm 1.4$ & $12.5 \pm 3.2$ & $10.5 \pm 2.3$ & n.s. & n.s. & n.s. \\
\hline F/B ratio & $0.016 \pm 0.002$ & $0.012 \pm 0.004$ & $0.021 \pm 0.004$ & $0.017 \pm 0.003$ & $0.022 \pm 0.007$ & $0.024 \pm 0.004$ & n.s. & n.s. & n.s. \\
\hline
\end{tabular}

$M B C$ microbial biomass $C, M B N$ microbial biomass $N, M B P$ microbial biomass $P, B G \beta$-glucosidase, $N A G \beta$ - $N$-acetyl-glucosaminidase, $A C P$ acid phosphatase; bacteria biomass is represented by the copy number of $16 \mathrm{~S}$ rRNA; fungi biomass is represented by the copy number of ITS gene; F/B ratio was calculated by the ratio of ITS and $16 \mathrm{~S}$ rRNA gene copy numbers, the same below. Data are displayed as means \pm standard errors $(n=5)$. The effects of the freeze-thaw cycle (FTC), soil horizon $(\mathrm{H})$, and their interaction $(\mathrm{FTC} \times \mathrm{H})$ are shown at the right columns. Bold lowercase letters indicate significant differences among different stages within the same horizon $(P<0.05)$. Two-way ANOVA results ${ }^{*} P<0.05,{ }^{* *} P<0.01,{ }^{* * *} P<0.001$ and n.s. not significant

\section{Microbial diversity and community composition}

In the O-horizon soil, the bacterial diversity increased in response to the first FTC (stage II) but decreased after successive FTCs (stage III) (Fig. 2a, c). However, there was no significant change in bacterial diversity in the A-horizon soil during the different freeze-thaw periods (Fig. 2a, c). No significant differences in fungal diversity were observed at each freeze-thaw stage (Fig. 2b, d). The CPCoA analysis revealed that soil freeze-thaw accounted for $37.2 \%$ of the variation in bacterial community composition $(P=0.0019), 65.65 \%$ of which could be explained by the first two axes (Fig. 3a). The bacterial community composition at stage II (the first FTC) significantly differed from that at the other FTC stages (I and III), and no significant difference was found between other stages, regardless of the soil horizon. In contrast, freeze-thawing had no significant effect on the fungal community composition $(P=0.94)$ (Fig. 3b). The fungi:bacteria ratio of the microbial community showed no significant change across all FTCs (Table 2). We found that the first FTC (stage II) significantly increased the relative abundance of Bacteroidetes in the O-horizon soil, whereas it increased the relative abundance of Proteobacteria and decreased that of Acidobacteria and Chloroflexi in the A-horizon soil (Fig. 4a, Additional file 1: Fig. S6). Regarding fungal composition, only the abundance of the
Mortierellomycetes class in the O-horizon soil was significantly higher at stage II than at stages I and III (Fig. 4b). The number of identical OTUs detected across the three sampling stages was 6,092 and 4,846, accounting for $37.5 \%$ and $34.2 \%$ of the total bacterial population in the $\mathrm{O}$ and A horizon, respectively (Additional file 1: Fig. S7). Additionally, the largest number of unique OTUs was found at stage II, with 2,666 (16.4\%) in the O horizon and 2,566 (18.1\%) in the A horizon (Additional file 1: Fig. S7).

\section{Extracellular enzyme activity and bacterial functional potentials}

Among the three extracellular enzymes studied, the $\mathrm{C}$-acquiring enzyme (BG) activity changed most noticeably across different FTC stages and soil horizons. The highest BG activity was detected in soil samples collected after the first FTC (stage II), being at least $48.7 \%$ higher than that of other periods in the O-horizon soil and twice as high as that of other periods in the A-horizon soil (Table 2). The activity of the N-acquiring (NAG) and $\mathrm{P}$-acquiring $(\mathrm{ACP})$ enzymes changed notably only in the A- and O-horizon soils, respectively, and the highest activity occurred at stage II (Table 2). The intensity of enzyme responses to FTCs differed, leading to a significant variation in the stoichiometry of the enzymes among the different periods. The enzyme $\mathrm{C} / \mathrm{N}$ acquisition 

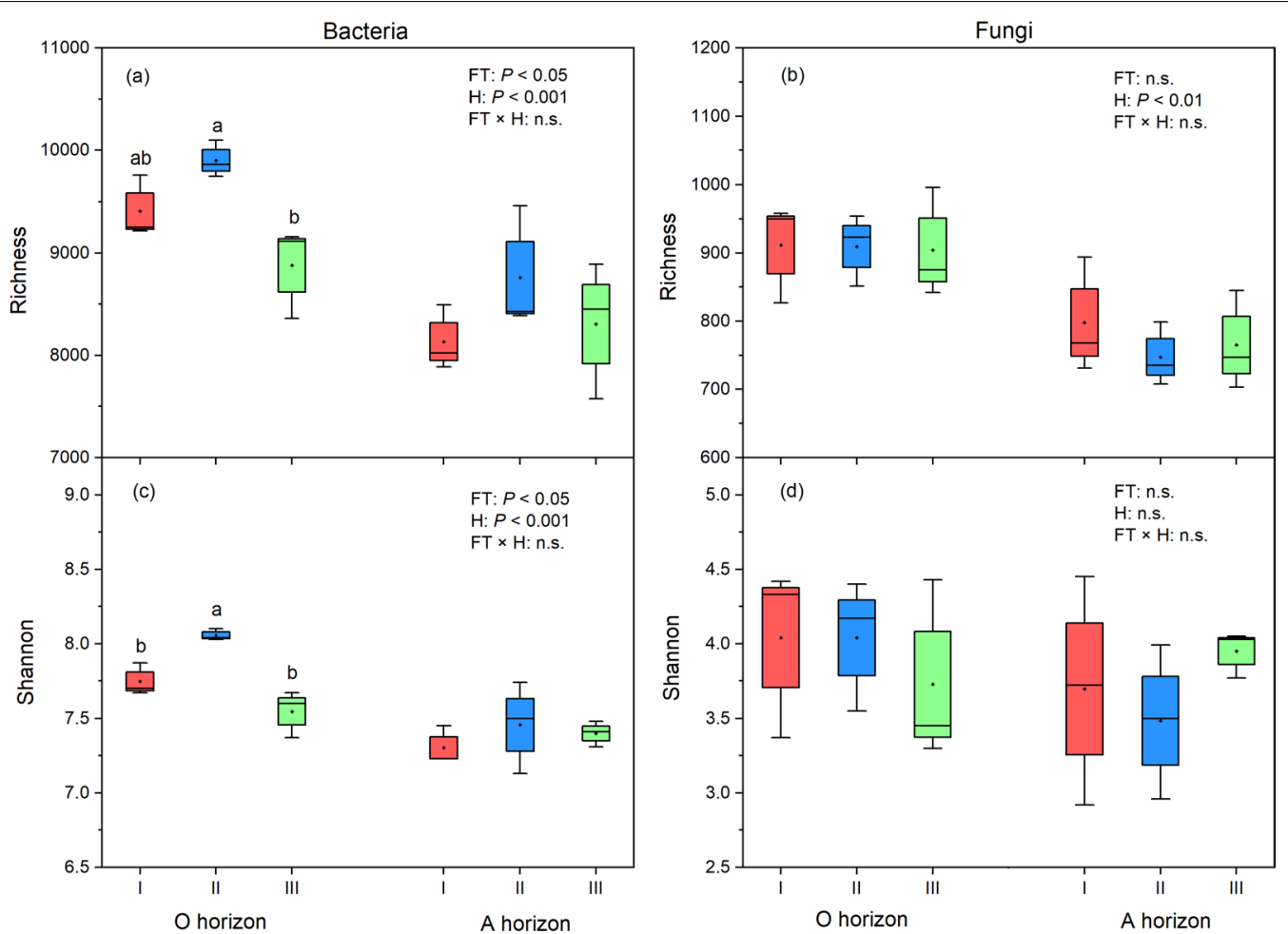

Fig. 2 Alpha diversity indexes (richness and Shannon) of soil $(\mathbf{a}, \mathbf{c})$ bacterial and (b, d) fungal community at different freeze-thaw stages. The effects of freeze-thaw treatment (FT), soil horizon $(\mathrm{H})$, and their interaction (FT $\times H)$ are shown in the figure. Lowercase letters indicate significant differences among different stages in each soil horizon $(P<0.05)$. Box indicates mean \pm standard error $(n=3)$

activity ratio (BG/NAG) remained unchanged throughout all stages in both $\mathrm{O}$ - and A-horizon soils (Table 2). In contrast, significant increases in the enzyme $\mathrm{C} / \mathrm{P}$ acquisition activity ratio (BG/ACP) and enzyme $\mathrm{N} / \mathrm{P}$ acquisition activity ratio (NAG/ACP) were observed at stage II in the A-horizon soil (Table 2).

In our study, 91 functional categories were matched when the bacterial community was linked to the FAPROTAX database. The first FTC significantly promoted photoheterotrophy, photoautotrophy, fermentation, nitrate_reduction, denitrification, and ureolysis processes (stage II vs. stage I), which declined after successive FTCs in the O-horizon soil (stage III vs. stage II, Additional file 1: Fig. S8). In contrast, increased photoautotrophy, aromatic_compound_degradation, nitrate_reduction, and ureolysis processes at the first FTC (stage II vs. stage I) did not decline significantly after successive FTCs in the A-horizon soil, except for aromatic_compound_degradation (stage III vs. stage II, Additional file 1: Fig. S8). The abundance of these functional categories (except for cellulolysis) was significantly higher in the O-horizon soil than in the A-horizon soil (Additional file 1: Fig. S8). The abundance of fungal functional groups with different trophic modes was compared and no significant difference among different stages was found (Additional file 1: Fig. S9a). We matched 57 guilds from the FUNGuild database when predicting the fungal functional potentials, 16 of which have relatively high abundance. Undefined saprotroph-wood saprotroph and plant saprotroph-wood saprotroph increased significantly after the first FTC, and undefined saprotroph-undefined symbiotroph increased significantly after repeated FTCs for both horizons. In addition, soil saprotroph decreased significantly in the A horizon after the first FTC (Additional file 1: Fig. S9b). The abundance level of bacterial and fungal functional categories at the end of the study did not change significantly compared with the stage before FTC occurred in both soil horizons (stage III vs. stage I, Additional file 1: Fig. S8, S9).

\section{Relationship between soil properties and microbial diversity and community composition}

Regression analysis showed that the increase in SWC, DOC, $\mathrm{NH}_{4}{ }^{+}-\mathrm{N}$, and TDP significantly increased the alpha diversity (richness and Shannon indexes) of bacteria (Fig. 5a-d), but had no remarkable effect on that of fungi (Fig. 5e-h). The Mantel test showed that SWC, DOC, $\mathrm{NH}_{4}{ }^{+}-\mathrm{N}$, and TDP were also highly positively correlated 


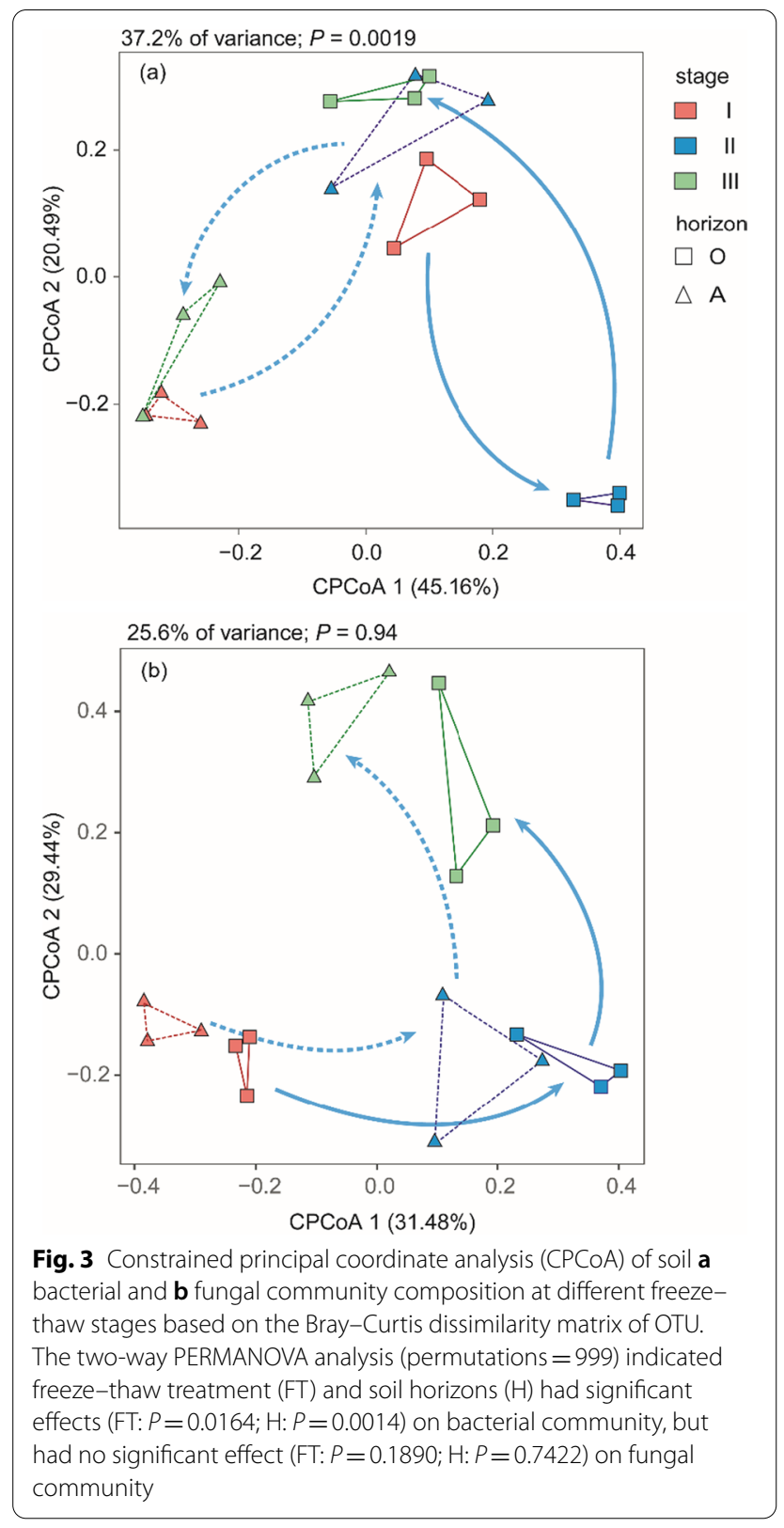

with bacterial community composition in both $\mathrm{O}$ - and A-horizon soils (Table 3). Moreover, soil $\mathrm{pH}$ and $\mathrm{SOC} /$ TN contributed to the shifts in bacterial community composition in the O-horizon soil, as did SOC, TN, TP, TDN, DON, and DOC/TDN in the A-horizon soil (Table 3). The first two components of the RDA axes explained most of the variation (67.76\% and $68.61 \%$ for $\mathrm{O}$ - and A-horizon soil, respectively) in the composition of the dominant bacterial phyla (Fig. 6). Seven of the detected environmental variables had relative great effects on determining the ordination pattern of the bacterial community, among which soil $\mathrm{NH}_{4}{ }^{+}-\mathrm{N}$ and DOC/TDN accounted for $34.7 \%(P=0.021)$
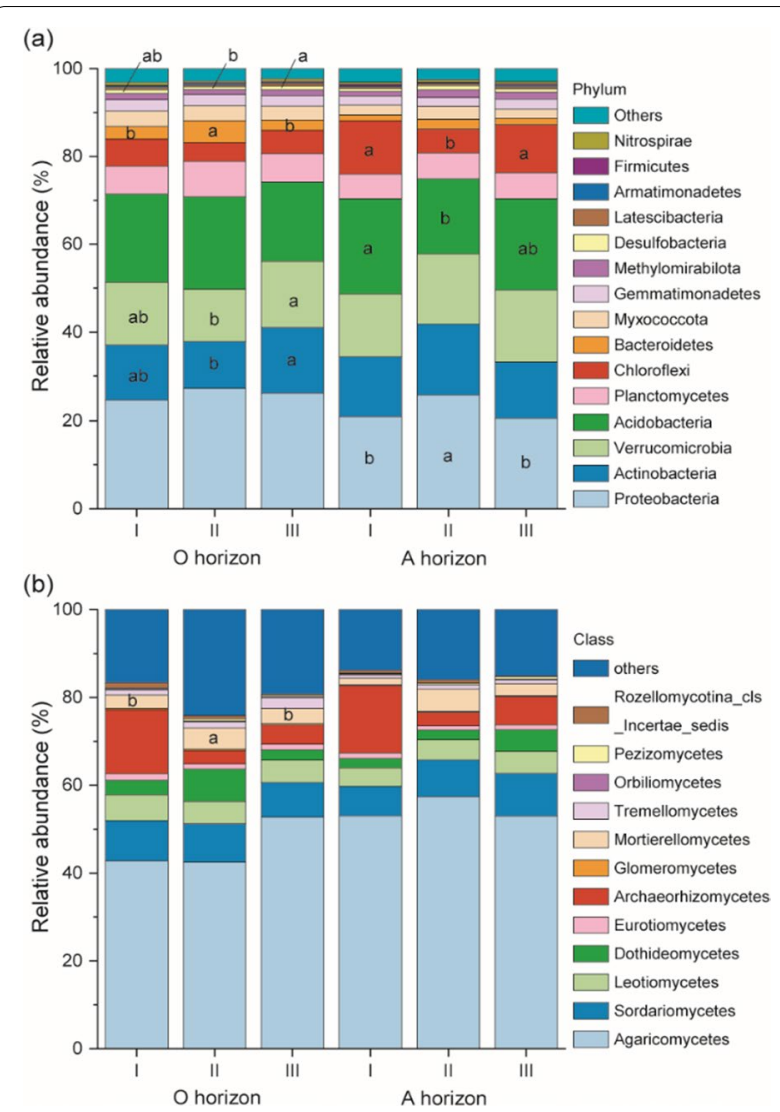

Fig. 4 Relative abundance of $\mathbf{a}$ bacterial and $\mathbf{b}$ fungal community at the phylum and class level among different freeze-thaw stages, respectively. Different letters within the same horizon indicate significant differences among different stages for each soil horizon. The changes in the relative abundance of bacterial communities at the more detailed taxonomic level (genus level) are shown in Additional file 1: Fig. S6

and $32.3 \%(P=0.023)$ of the variation in the dominant bacterial phyla in the O-horizon soil, respectively (Fig. 6a). Soil $\operatorname{DON}(P=0.002)$, TDP $(P=0.004)$, DOC/TDN $(P=0.010)$, and DOC $(P=0.021)$ contributed significantly to the overall ordination pattern of the dominant bacterial phyla in the A-horizon soil (Fig. 6b). The first two RDA axes explained a small part of the variation $(41.81 \%$ and $26.11 \%$ for $\mathrm{O}$ - and A-horizon soil, respectively) in the dominant fungal class composition (Fig. S10), and only SOC/TN of the seven environmental variables could significantly explain the variation in the fungal community $(P=0.012)$ (Fig. S10a).

\section{Discussion}

Regulation of soil environmental factors by FTCs at different stages

The initial freeze-thaw process greatly increased nutrient availability in the soil, but a significant decrease was 

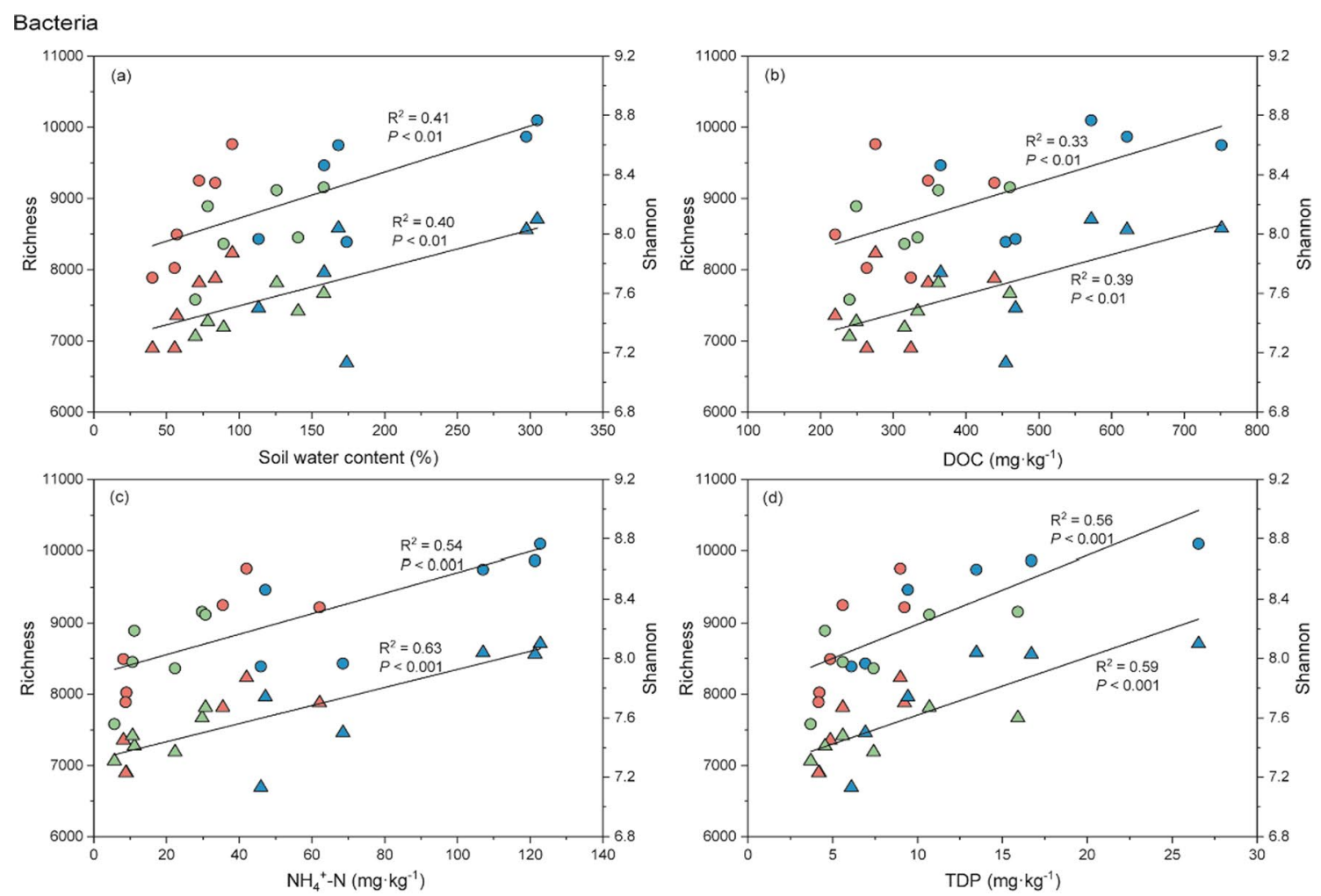

Fungi
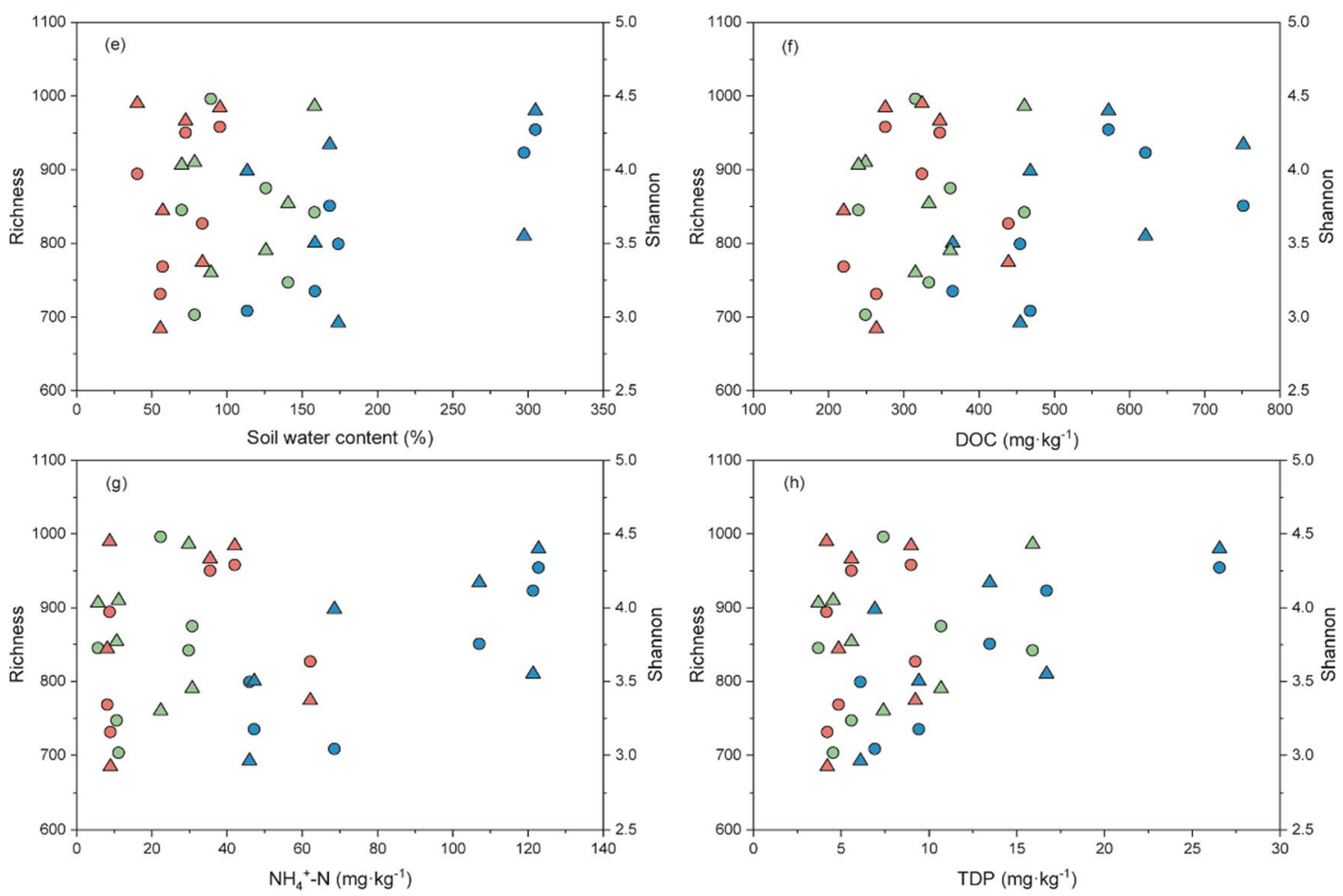

$\square$ I $\square$ II $\square$ III $O$ Richness $\triangle$ Shannon

Fig. 5 Regressions between microbial diversity indexes (richness and Shannon) and $\mathbf{a}, \mathbf{e} \mathrm{SWC}, \mathbf{b}, \mathbf{f} \mathrm{DOC}, \mathbf{c}, \mathbf{g ~ N H}{ }_{4}{ }^{+} \mathrm{N}$, and $\mathbf{d}$, $\mathbf{h}$ TDP for bacterial community (a-d) and fungal community (e-h) 
Table 3 Mantel test results to discern correlation between soil physicochemical variables (based on Euclidian distances) and the bacterial community composition (based on Bray-Curtis distances of OTUs)

\begin{tabular}{|c|c|c|c|c|}
\hline \multirow[t]{2}{*}{ Properties } & \multicolumn{2}{|c|}{ O horizon } & \multicolumn{2}{|c|}{ A horizon } \\
\hline & $r$ & $P$ & $r$ & $P$ \\
\hline $\mathrm{pH}$ & 0.53 & 0.017 & 0.25 & 0.165 \\
\hline SWC & 0.43 & 0.038 & 0.36 & 0.043 \\
\hline SOC & 0.27 & 0.064 & 0.57 & 0.009 \\
\hline TN & 0.07 & 0.302 & 0.49 & 0.018 \\
\hline TP & 0.00 & 0.485 & 0.43 & 0.049 \\
\hline $\mathrm{SOC} / \mathrm{TN}$ & 0.39 & 0.036 & 0.15 & 0.176 \\
\hline $\mathrm{SOC/TP}$ & 0.14 & 0.229 & 0.38 & 0.06 \\
\hline TN/TP & 0.05 & 0.367 & 0.28 & 0.11 \\
\hline DOC & 0.44 & 0.016 & 0.37 & 0.031 \\
\hline TDN & 0.25 & 0.091 & 0.62 & 0.008 \\
\hline DON & 0.06 & 0.297 & 0.64 & 0.011 \\
\hline $\mathrm{NH}_{4}{ }^{+}-\mathrm{N}$ & 0.58 & 0.004 & 0.62 & 0.004 \\
\hline $\mathrm{NO}_{3}{ }^{-}-\mathrm{N}$ & -0.20 & 0.757 & 0.34 & 0.075 \\
\hline TDP & 0.46 & 0.027 & 0.77 & 0.001 \\
\hline AP & -0.28 & 0.944 & -0.12 & 0.776 \\
\hline DOC/TDN & -0.07 & 0.614 & 0.63 & 0.003 \\
\hline DOC/TDP & 0.24 & 0.121 & 0.33 & 0.068 \\
\hline TDN/TDP & 0.01 & 0.412 & 0.26 & 0.173 \\
\hline
\end{tabular}

OTU operational taxonomic unit observed after repeated FTCs. The content of soil soluble nutrients (e.g., DOC, TDN, $\mathrm{NH}_{4}{ }^{+}-\mathrm{N}$, TDP, etc.) increased substantially when the first freeze-thaw occurred (Table 1), a finding which has been reported in previous studies (Koponen et al. 2006; Yang et al. 2019). The observed increment in nutrients was generally considered to originate mainly from soil aggregate breakdown and microbial damage (Yu et al. 2010; Risk et al. 2013). The temperature fluctuation and water phase transformation caused by FTCs may have disrupted the soil aggregate structure (Chai et al. 2014) and exposed the organic matter that was previously physically protected (van Bochove et al. 2000). The apparent macroaggregate reduction, accompanied by the increase in microaggregates at the first FTC in the O horizon, also confirmed FTC damage to soil aggregate structure in this study. The significant increases of SOC and TN content at stage II relative to those at stage I (Table 1) indicated that litter and roots may have contributed to the increase in the soil $\mathrm{C}$ and $\mathrm{N}$ pools because mass loss and nutrient release from plant roots and litter during FTCs can be exacerbated by mechanical fragmentation, hydraulic leaching, and microbial action (Tierney et al. 2001). However, repeated FTCs may have gradually weakened the release of soil available nutrients because of a tendency toward soil structure stabilization. Loss of soil available nutrients by leaching and consumption in biological activity for
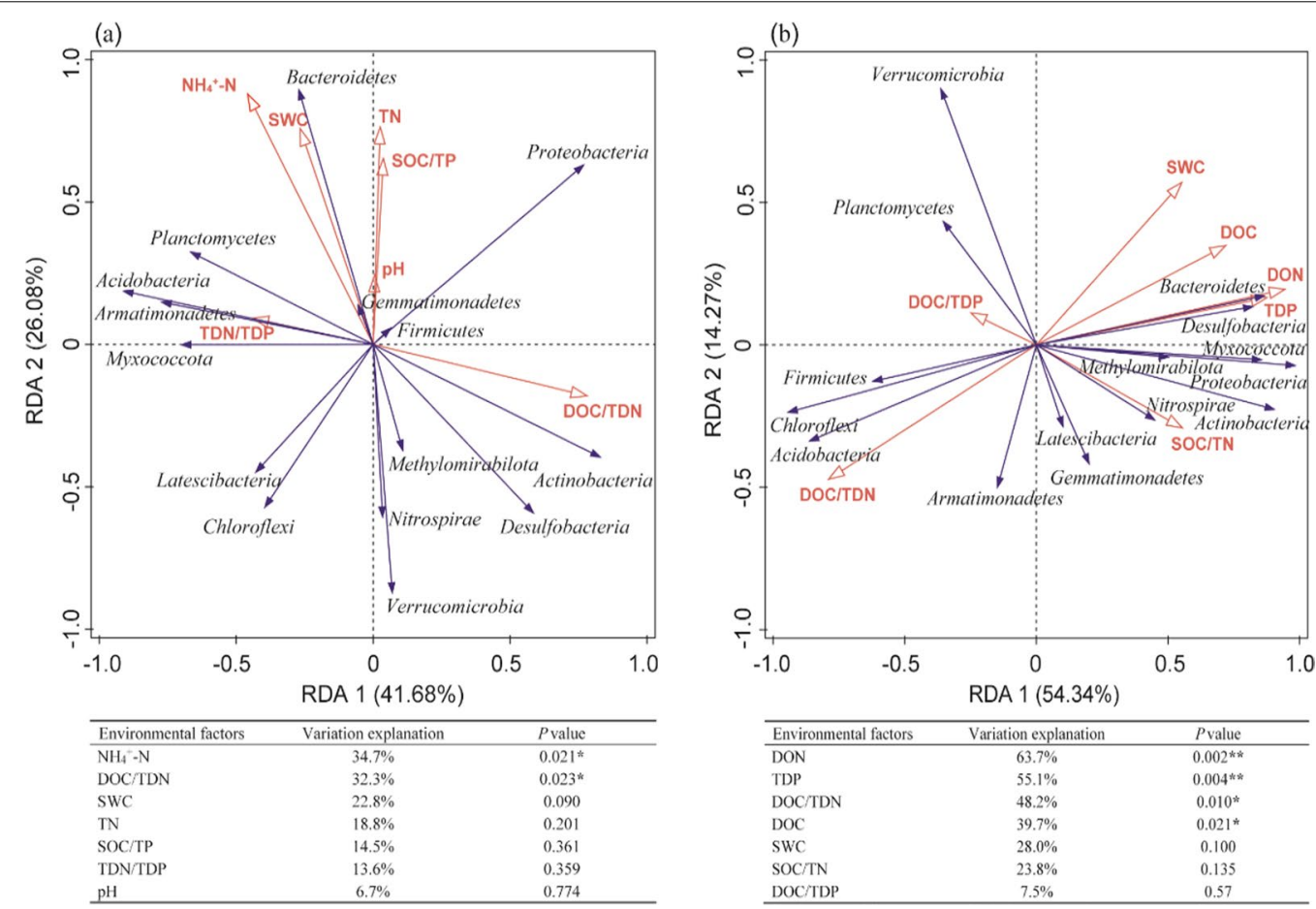

Fig. 6 Environmental explanation of the changes in abundance of the top 15 bacterial phyla by RDA analysis in $\mathbf{a} O$ horizon and $\mathbf{b} \mathrm{A}$ horizon soil. The blue arrows indicate bacterial phyla, and the red arrows present soil properties. ${ }^{*} P<0.05$; ${ }^{*} P<0.01$ Unrestricted permutation test, $n=999$ 
adaptation to freeze-thaw effects may also have contributed to the observed decrease in available nutrients (Feng et al. 2007). All these factors could have contributed to the decline in soluble soil nutrient content after successive FTCs (Table 1).

SWC is important for biological reactions and nutrient transport in soils (Öquist et al. 2009). In addition, soil microbial functions are intimately tied to the magnitude and connectivity of water films around soil particles (Stefan et al. 2014). Low water content increases osmotic stress and decreases microbial mobility and degradative activity by reducing nutrient availability (Chodak et al. 2015). High water content favors nutrient diffusion, but it could cause an anoxic environment and inhibit aerobic microbial activity (Supramaniam et al. 2016). Water content plays a vital role as an indicator of soil nutrient availability (Bechmann et al. 2005). Water availability is a key driver of the destruction of soil structure and microbial cells (Kvaernø and Øygarden 2006), promoting the release, migration, and infiltration of nutrients (Yanai et al. 2004) and regulating the soil microenvironment and microbial metabolism (Rivkina et al. 2000; Schimel and Mikan 2005) during the FTC process. Owing to the dynamic equilibrium within the soil-water system, the nutrient content in surface runoff depends on that in the soil, possibly accounting for the high values observed during the initial FTC period and the gradual decrease during repeated FTCs (Additional file 1: Figs. S2, S3). Because surface runoff during the entire FTC process may have caused considerable nutrient loss from the soil, it appears that the FTCs were disadvantageous to soil nutrient fixation and soil fertility maintenance in our study.

\section{Environmental controls on microbial biomass, diversity, and community composition}

Most studies from indoor simulation experiments have shown that the first freeze-thaw may kill up to half of the microorganisms (Koponen et al. 2006; Sawicka et al. 2010), which contradicts the results of our field experiment. We found that soil total microbial biomass (represented by MBC concentration) showed a slight increase, rather than a sharp decrease when the soil thawed for the first time after long-term freezing (Table 2). This difference may be attributed to the integrity of the soil profile and stability of the microbial habitat conditions in the soil in an in situ context compared with the excavated soil used in simulation experiments (Song et al. 2017). Two underlying mechanisms may explain the microbial stability we observed at the initial FTC stage: (1) the microorganisms surviving in the long-term cold environment may have had strong resistance and could, therefore, tolerate moderate temperature fluctuations (from -1 to $2{ }^{\circ} \mathrm{C}$,
Fig. 1a) during the first FTC (Lipson et al. 2000; Grogan et al. 2004; Wang et al. 2015). (2) Abundant available substrates and improved hydrothermal conditions may have accelerated the growth and reproduction of microorganisms, counteracting or even surpassing the effect of microorganism death (Koponen et al. 2006; Zhang et al. 2017). We observed that the soil MBC decreased significantly following continuous FTCs (Table 2), a finding consistent with previous results (Yanai et al. 2004; Sorensen et al. 2018). Jefferies et al. (2010) attributed this decline to factors such as low nutrient availability and cell membrane rupture caused by FTCs. In the present study, the bacterial biomass (expressed by $16 \mathrm{~S}$ rRNA gene copy number) coincided well with $\mathrm{MBC}$, whereas the fungal biomass (expressed by ITS gene copy number) was unaffected by freeze-thaw alternation (Table 2). This implies that the change in microbial biomass was mainly dominated by bacteria; the bacteria may have quickly adapted and responded to the environmental changes caused by the freeze-thaw action, whereas the fungi maintained constant biomass, most probably relying on strong resistance (Feng et al. 2007). Previous studies have reported that sufficient nutrient supply decreased soil microbial diversity across cropland, grassland, forest, and tundra ecosystems (Zeng et al. 2016; Zhou et al. 2017), and there have also been reports of no change (Fierer et al. 2012) or an increase (Turlapati et al. 2013; O'Brien et al. 2016) in microbial diversity after nutrient addition in fertilization experiments. Low-nutrient frozen soil can support only some of the cryotolerant, oligotrophic bacterial species (Edwards et al. 2006), and the sharp increase in quantity and quality of accessible nutrients after thawing promotes and favors a more active, broad, copiotrophic microbial community. A similar effect in our study may explain why bacterial diversity (reflected by the richness and Shannon indexes) peaked in the O-horizon soil after the first freeze-thaw. We did find that the environmental conditions after the first freeze-thaw preserved the broadest bacterial richness according to the interaction of OTU numbers at each stage (Additional file 1: Fig. S7). After frozen soil thawing, sufficient water and nutrients (DOC, $\mathrm{NH}_{4}{ }^{+}-\mathrm{N}, \mathrm{TDP}$ ) may have entered the soil profile, producing irrigation and fertilization effects, which may have met different metabolic preferences of the bacterial communities and facilitated the increase in bacterial community diversity (Fig. 5a-d). This increase in diversity was probably a short-term compensation response to a sudden improvement in typically harsh environmental conditions, as the decline in soil water and nutrient availability after successive FTCs led to a significant decline in bacterial diversity. Such an initial increase in bacterial diversity has the potential to result in increased $\mathrm{C}$ and nutrient cycling, which could have led to a decline in 
soil C storage potential (Weidner et al. 2015). Based on the previous studies of Yang et al. (2017) and Sun et al. (2016), we can infer why the diversity of fungal communities did not change significantly from beginning to end: soil $\mathrm{pH}$ and SOC content are two important soil properties affecting fungal diversity, however, $\mathrm{pH}$ changed slightly during our experiment period, and fungi that tend to k-strategy had no competitive advantage against a large number of copiotrophic bacteria in the early stage of FTCs with the highest SOC content, so it was difficult to break through the original patterns of richness and Shannon index. In addition, the alternation of soil freezing and thawing will inevitably destroy the mycelial structure of fungi and restrict the development of the fungal community (Campbell et al. 2014).

Moreover, in the present study, FTCs reshaped the microbial community structure. Song et al. (2017) reviewed several reports and found that FTCs significantly lowered the microbial $\mathrm{C} / \mathrm{N}$ ratio, suggesting that the microbial community composition was predominantly bacterial, a finding observed in our experiments (Table 2). With sufficient labile substrates, the bacterial community, as $\mathrm{r}$-strategists, is likely to become dominant in the microbial community (Sjursen et al. 2005), and this was evidenced by the differential characteristics of the bacterial and fungal community composition at different FTC stages. In addition, the bacterial community at stage II significantly differed from that at stages I and III (Fig. 3a), and the changes in the relative abundance of several preponderant phyla and their composition during FTCs could be well explained by the oligotrophic-copiotrophic theory (Fierer et al. 2007) combined with available nutrients such as $\mathrm{NH}_{4}{ }^{+}-\mathrm{N}, \mathrm{DON}$, TDP, and DOC. As expected, the increased nutrient availability after the first FTC increased the relative abundance of the typical copiotrophic bacterial taxa such as Proteobacteria and Bacteroidetes and decreased the proportion of the so-called oligotrophic groups, represented by Acidobacteria and Verrucomicrobia, whereas the low nutrient availability at the end of the FTCs reduced the abundance of Proteobacteria and Bacteroidetes. These findings are consistent with those of previous studies (Fierer et al. 2007, 2012; Leff et al. 2015). Actinobacteria have always been regarded as a copiotrophic taxon; however, Actinobacteria showed a low abundance at the relatively nutrient-rich stage II (Fig. 4), suggesting that this phylum responds mainly to other soil properties, such as SWC, as reflected in its previously reported negative response to the increase in water availability (Barnard et al. 2013; Bouskill et al. 2013). In addition, Perez-Mon et al. (2020) found that soil temperature is also related to changes in community composition owing to its positive effects on copiotrophic microorganisms. Regarding fungi, Mortierellomycetes was the only fungal group that showed significant changes during FTCs, indicating that most fungal taxa were not affected by FTCs. The different responses to FTCs between bacterial and fungal communities indicated that bacteria were more sensitive than fungi to environmental changes, resulting in the large variation in bacterial community composition and diversity and the relative stability in fungal community composition and diversity during FTCs in this study.

\section{Functional potential changes of microbial communities driven by FTCs}

The potential activity of the three extracellular enzymes BG, NAG, and ACP is usually related to microbial C, N, and $\mathrm{P}$ metabolic rates and biogeochemical processes and is used to indicate microbial $\mathrm{C}, \mathrm{N}$, and $\mathrm{P}$ requirements (Schimel and Weintraub 2003; Moorhead and Sinsabaugh 2006). Microbes are expected to preferentially allocate a large proportion of resources to acquire the most limiting nutrient (Bloom et al. 1985); therefore, the activity of different nutrient acquiring enzymes may change disproportionately owing to the considerable environmental shift caused by the FTCs. Consequently, soil extracellular enzyme activity ratios are not homeostatic and are regulated by various abiotic and biotic factors. The highest potential $\mathrm{C}$-, $\mathrm{N}$-, and $\mathrm{P}$-acquiring activities observed at stage II were suggestive of vigorous microbial metabolism (Table 2) (Sinsabaugh et al. 2009). The microbial C and $\mathrm{N}$ acquisition process remained coupled during the FTCs, and the enzyme activity ratios of $\mathrm{C} / \mathrm{P}$ at stage II were significantly higher than those at stages I and III, implying intense energy $(\mathrm{C})$ demand relative to $\mathrm{P}$ when the first freeze-thaw occurred and suggesting that substrate $C$ availability in the environment was highly likely to control the prevailing microbial activity pattern (Peng and Wang 2016). The enzyme N/P activity ratio in the A-horizon soil at stage II was also higher than that during the other periods (Table 2), demonstrating that, after the first freeze-thaw, microbial metabolism shifted to facilitate $\mathrm{N}$ acquisition, which may be a response to the lower $\mathrm{N}$ availability relative to $\mathrm{P}$ availability caused by increased $\mathrm{N}$ loss in the soil (Allison et al. 2007).

Considering the significant differentiation of community structure, we predicted $\mathrm{C}$ and $\mathrm{N}$ metabolic processes of the bacterial community. The initial freezethaw not only enhanced the decomposition processes of soil organic matter, such as fermentation, but also elevated the photoautotrophy and photoheterotrophy processes, suggesting that the enhanced bacterial growth was accompanied by increased demand for $\mathrm{C}$ resources, as evidenced by the slight increase in bacterial biomass and MBC (Table 2). However, accelerated activation, rapid utilization, surface runoff, and leaching 
loss of organic $\mathrm{C}$ under freeze-thaw action may reduce soil $\mathrm{C}$ sequestration. For the $\mathrm{N}$ metabolic processes, the initial FTC increased nitrate_reduction, denitrification, and ureolysis, indicating that organic $\mathrm{N}$ mineralization was enhanced, which ultimately increased $\mathrm{N}$ availability (Table 1) (Li et al. 2019). Meanwhile, a high N content, together with anaerobic conditions caused by high SWC, stimulated bacterial denitrification and $\mathrm{NO}_{3}{ }^{-}-\mathrm{N}$ reduction process (Xu and Cai 2007), partly explaining the decrease in soil $\mathrm{NO}_{3}{ }^{-}-\mathrm{N}$ content in the initial FTC stage (Table 1). In the context of FTCs, these processes hinder soil $\mathrm{N}$ immobilization and risk accelerating soil $\mathrm{N}$ loss in gaseous or leachable states. The most obvious change of fungal functional guilds was that undefined saprotrophwood saprotroph and undefined saprotroph-undefined symbiotroph changed in the opposite direction during the experiment period (when the former increased, the latter decreased, and vice versa), which may be because the release of organic matter at the early stage of FTCs stimulated the activities of saprophytic fungi with decomposition function (Sun et al. 2016), while the hyphae of symbiotic fungi were destroyed under the initial freezethaw pressure, or the sufficient nutrients released after FTCs no longer supported the growth and expansion of the mycelia (Treseder et al. 2018).

\section{Conclusions}

We determined the dynamics of soil properties and soil microbial communities in a field FTC experiment in a temperate forest and found that FTCs significantly affected the community structure, diversity, and function of soil bacteria but not those of fungi. Moreover, there were temporal differences in these effects; a moderate initial FTC was beneficial, whereas repeated subsequent FTCs were harmful to the growth and reproduction of the bacterial community. The FTCs at different stages provided important reference for forest ecosystem $\mathrm{C}$ and nutrients cycling. Our results suggested that FTCs could activate the substrate resources in the soil to a certain extent, accelerating $\mathrm{C}, \mathrm{N}$, and $\mathrm{P}$ utilization by microorganisms as well as loss through gas emission, leaching, or surface runoff. The SWC, DOC, $\mathrm{NH}_{4}{ }^{+}-\mathrm{N}$, and TDP as available resources were important driving factors for determining the composition and diversity of the bacterial community during FTCs. We can forecast the soil $\mathrm{C}$ and $\mathrm{N}$ storage states in temperate forest soils from the perspective of enzyme activity and metabolic potentials. Our research indicated that microorganisms under FTCs tend to reduce soil $\mathrm{C}$ sequestration and $\mathrm{N}$ stability, which may aggravate nutrient loss in different forms and negatively affect nutrient supply in the coming growing season, and even be unfavorable to the functional restoration of the local forest ecosystems. Furthermore, our research contributes a deeper understanding of the changes in soil microbial communities at high latitude or alpine areas and improves our predictions of the dynamics of soil $\mathrm{C}$ and $\mathrm{N}$ cycles in this type of ecosystem in response to climate change.

\begin{abstract}
Abbreviations
FTC: Freeze-thaw cycle; SWC: Soil water content; DOC: Dissolved organic carbon; $\mathrm{NH}_{4}{ }^{+}-\mathrm{N}$ : Ammonium nitrogen; TDP: Total dissolved phosphorus; SOC: Soil organic carbon; TN: Total nitrogen; TP: Total phosphorus; AP: Available phosphorus; MBC: Microbial biomass carbon; MBN: Microbial biomass nitrogen; MBP: Microbial biomass phosphorus; TDN: Total dissolved nitrogen; $\mathrm{NO}_{3}{ }^{-}$-N: Nitrate nitrogen; DON: Dissolved organic nitrogen; BG: $\beta-$ Glucosidase; NAG: N-Acetyl-glucosaminidase; ACP: Acid phosphatase; qPCR: Quantitative polymerase chain reaction; OTU: Operational taxonomic unit; FAPROTAX: Functional Annotation of Prokaryotic Taxa; CPCoA: Constrained principal coordinate analysis; RDA: Redundancy analysis.
\end{abstract}

\section{Supplementary Information}

The online version contains supplementary material available at https://doi. org/10.1186/s13717-021-00337-x.

Additional file 1: Fig. S1. Relationships between soil water content (SWC) and (a) DOC, (b) TDN, (c) TDP, and (d) $\mathrm{NH}_{4}{ }^{+}-\mathrm{N}$ concentration during freeze-thaw cycles. Fig. S2. Changes in nutrient content in surface water flowing through sampling plot. The $c-h$ letters along the horizontal axis represented six sampling dates, $c$ was the sampling date when surface runoff appeared, $d$ and $h$ corresponded to stage II and stage III of FTCs in this study, respectively. $e, f$, and $g$ were three sampling dates between stages II and III of FTCs. More details refer to Fig. 1. Different uppercase letters indicate significant differences among different sampling dates. Fig. S3. Dynamic changes of soil (a) DOC, (b) TDP, (c) TDN, (d) DON, (e) $\mathrm{NH}_{4}{ }^{+}-\mathrm{N}$, and (f) $\mathrm{NO}_{3}{ }^{-}-\mathrm{N}$ content during the experiment period. Different letters within the same horizon indicate significant differences among different sampling dates. Fig. S4. Dynamic changes of soil MBC content during the experiment period. Different letters within the same horizon indicate significant differences among different sampling dates. Fig. S5. Soil water-stable aggregate composition at different freeze-thaw stages. > $2000 \mu \mathrm{m}$, large macroaggregate; 250-2000 $\mu \mathrm{m}$, small macroaggregate; $53-250 \mu \mathrm{m}$, microaggregate; $<53 \mu \mathrm{m}$, silt and clay. Fig. S6. Relative abundance of bacterial community at the genus level among different freeze-thaw stages. Different letters within the same horizon indicate significant differences among different stages for each bacterial genus. Note: Candidatus_Udaeobacter genus belongs to Verrucomicrobia phylum, HSB_OF53-F07 genus belongs to Chloroflexi phylum, IMCC26256 and Mycobacterium genus belong to Actinobacteria phylum, and Subgroup_5 genus belongs to Acidobacteria phylum. Fig. S7. A Venn diagram showing the interactions of the OTUs from different freeze-thaw stages in (a) $\mathrm{O}$ - and (b) A-horizon soils. Fig. S8. The relative abundance of putative bacterial functional categories based on the FAPROTAX database at different freeze-thaw stages. Different letters in the same soil horizon indicate significant differences between different stages $(P<0.05)$. The soil horizon effect is also shown above, and red asterisks indicate positive effects and blue asterisks indicate negative effects. ${ }^{*} P<0.05, * * P<0.01$. Fig. S9 The relative abundance of putative fungal (a) trophic mode and (b) functional guilds based on the FUNGuild database at different freezethaw stages. Different letters in the same soil horizon indicate significant differences between different stages $(P<0.05)$. Fig. S10. Environmental explanation of the changes in fungal abundance of the top 12 classes by RDA analysis in (a) $O$ horizon and (b) A horizon soil. The blue arrows indicate fungal classes, and red arrows present soil properties. ${ }^{*} P<0.05$. Unrestricted permutation test, $n=999$. 


\section{Acknowledgements}

Thanks to anonymous reviewers for their comments. This study was supported by the National Natural Science Foundation of China (31770531, 32001174), the Key Research Program of Frontier Sciences, CAS (QYZDB-SSW-DQC006), the Key Laboratory of Geographical Processes and Ecological Security of Changbai Mountains, Ministry of Education (GPES201902), the Youth Innovation Promotion Association CAS to Chao Wang (2018231).

\section{Authors' contributions}

ZX, CW, and EB designed the study. CS, LS, PJ and ZX conducted the field and laboratory analyses. Data analysis was conducted by CS, HS, and ZX. The paper was written by CS, ZX, and CW with input from the other authors. All authors read and approved the final manuscript.

\section{Funding}

The National Natural Science Foundation of China (31770531, 32001174), the Key Research Program of Frontier Sciences, CAS (QYZDB-SSW-DQC006), the Key Laboratory of Geographical Processes and Ecological Security of Changbai Mountains, Ministry of Education (GPES201902), the Youth Innovation Promotion Association CAS to Chao Wang (2018231).

\section{Availability of data and materials}

All data are available in the main text or the supplementary materials and raw data are available upon request to the corresponding author. The raw sequences of bacteria and fungi have been deposited in the figshare (https:// doi.org/10.6084/m9.figshare.14847963.v1).

\section{Declarations}

Ethics approval and consent to participate

Not applicable.

\section{Consent for publication}

All authors agreed and approved the manuscript for publication in Ecological Processes.

\section{Competing interests}

The authors declare that they have no competing interests.

\section{Author details}

${ }^{1}$ CAS Key Laboratory of Forest Ecology and Management, Institute of Applied Ecology, Chinese Academy of Sciences, Shenyang 110016, China. ${ }^{2}$ University of Chinese Academy of Sciences, Beijing 100049, China. ${ }^{3}$ Shandong Provincial Key Laboratory of Water and Soil Conservation and Environmental Protection, College of Resources and Environment, Linyi University, Linyi 276000, China. ${ }^{4}$ Key Laboratory of Geographical Processes and Ecological Security in Changbai Mountains, Ministry of Education, School of Geographical Sciences, Northeast Normal University, Changchun 130024, China. ${ }^{5}$ Key Laboratory of Vegetation Ecology, Ministry of Education, Changchun 130024, China.

Received: 9 August 2021 Accepted: 13 October 2021 Published online: 22 October 2021

\section{References}

Ade LJ, Hu L, Zi HB, Wang CT, Lerdau M, Dong SK (2018) Effect of snowpack on the soil bacteria of alpine meadows in the Qinghai-Tibetan Plateau of China. Catena 164:13-22. https://doi.org/10.1016/j.catena.2018.01.004

Agnelli A, Ascher J, Corti G, Ceccherini MT, Nannipieri P, Pietramellara G (2004) Distribution of microbial communities in a forest soil profile investigated by microbial biomass, soil respiration and DGGE of total and extracellular DNA. Soil Biol Biochem 36(5):859-868. https://doi.org/10. 1016/j.soilbio.2004.02.004

Allison VJ, Condron LM, Peltzer DA, Richardson SJ, Turner BL (2007) Changes in enzyme activities and soil microbial community composition along carbon and nutrient gradients at the Franz Josef chronosequence, New Zealand. Soil Biol Biochem 39(7):1770-1781. https://doi.org/10.1016/j. soilbio.2007.02.006
Allison SD, LeBauer DS, Ofrecio MR, Reyes R, Ta A-M, Tran TM (2009) Low levels of nitrogen addition stimulate decomposition by boreal forest fungi. Soil Biol Biochem 41(2):293-302. https://doi.org/10.1016/j.soilbio.2008. 10.032

Barnard RL, Osborne CA, Firestone MK (2013) Responses of soil bacterial and fungal communities to extreme desiccation and rewetting. ISME J 7(11):2229-2241. https://doi.org/10.1038/ismej.2013.104

Bechmann ME, Kleinman PJA, Sharpley AN, Saporito LS (2005) Freeze-thaw effects on phosphorus loss in runoff from manured and catch-cropped soils. J Environ Qual 34(6):2301-2309. https://doi.org/10.2134/jeq2004. 0415

Bloom AJ, Chapin FS, Mooney HA (1985) Resource limitation in plants - An economic analogy. Annu Rev Ecol Syst 16(1):363-392. https://doi.org/ 10.1146/annurev.es.16.110185.002051

Bouskill NJ, Lim HC, Borglin S, Salve R, Wood TE, Silver WL, Brodie EL (2013) Pre-exposure to drought increases the resistance of tropical forest soil bacterial communities to extended drought. ISME J 7(2):384-394. https://doi.org/10.1038/ismej.2012.113

Brookes PC, Powlson DS, Jenkinson DS (1982) Measurement of microbial biomass phosphorus in soil. Soil Biol Biochem 14(4):319-329. https:// doi.org/10.1016/0038-0717(82)90001-3

Brookes PC, Landman A, Pruden G, Jenkinson DS (1985) Chloroform fumigation and the release of soil nitrogen: $A$ rapid direct extraction method to measure microbial biomass nitrogen in soil. Soil Biol Biochem 17(6):837-842. https://doi.org/10.1016/0038-0717(85)90144-0

Buée M, Reich M, Murat C, Morin E, Nilsson RH, Uroz S, Martin F (2009) 454 Pyrosequencing analyses of forest soils reveal an unexpectedly high fungal diversity. New Phytol 184(2):449-456. https://doi.org/10.1111/j. 1469-8137.2009.03003.x

Bünemann EK, Oberson A, Liebisch F, Keller F, Annaheim KE, Huguenin-Elie O, Frossard E (2012) Rapid microbial phosphorus immobilization dominates gross phosphorus fluxes in a grassland soil with low inorganic phosphorus availability. Soil Biol Biochem 51(3):84-95. https://doi.org/ 10.1016/j.soilbio.2012.04.012

Campbell JL, Socci AM, Templer PH (2014) Increased nitrogen leaching following soil freezing is due to decreased root uptake in a northern hardwood forest. Global Change Biol 20(8):2663-2673. https://doi.org/ $10.1111 / \mathrm{gcb} .12532$

Caporaso JG, Lauber CL, Walters WA, Berg-Lyons D, Lozupone CA, Turnbaugh PJ, Fierer N, Knight R (2011) Global patterns of 16S rRNA diversity at a depth of millions of sequences per sample. Proc Natl Acad Sci USA 108(S1):4516-4522. https://doi.org/10.1073/pnas.1000080107

Cavicchioli R, Ripple WJ, Timmis KN, Azam F, Bakken LR, Baylis M, Behrenfeld MJ, Boetius A, Boyd PW, Classen AT, Crowther TW, Danovaro R, Foreman CM, Huisman J, Hutchins DA, Jansson JK, Karl DM, Koskella B, Welch DBM, Martiny JBH, Moran MA, Orphan VJ, Reay DS, Remais JV, Rich VI, Singh BK, Stein LY, Stewart FJ, Sullivan MB, van Oppen MJH, Weaver SC, Webb EA, Webster NS (2019) Scientists' warning to humanity: microorganisms and climate change. Nat Rev Microbiol 17(9):569-586. https:// doi.org/10.1038/s41579-019-0222-5

Chai YJ, Zeng XB, E SZ, Bai LY, Su SM, Huang T, (2014) Effects of freeze-thaw on aggregate stability and the organic carbon and nitrogen enrichment ratios in aggregate fractions. Soil Use Manage 30(4):507-516. https:// doi.org/10.1111/sum.12153

Chen Y, Liu F, Kang L, Zhang D, Kou D, Mao C, Qin S, Zhang Q, Yang Y (2021) Large-scale evidence for microbial response and associated carbon release after permafrost thaw. Global Change Biol 27(14):3218-3229. https://doi.org/10.1111/gcb.15487

Chodak M, Gołębiewski M, Morawska-Płoskonka J, Kuduk K, Niklińska M (2015) Soil chemical properties affect the reaction of forest soil bacteria to drought and rewetting stress. Ann Microbiol 65(3):1627-1637. https:// doi.org/10.1007/s13213-014-1002-0

Cline LC, Hobbie SE, Madritch MD, Buyarski CR, Tilman D, Cavender-Bares JM (2018) Resource availability underlies the plant-fungal diversity relationship in a grassland ecosystem. Ecology 99(1):204-216. https://doi.org/ 10.1002/ecy.2075

de Scally SZ, Makhalanyane TP, Frossard A, Hogg ID, Cowan DA (2016) Antarctic microbial communities are functionally redundant, adapted and resistant to short term temperature perturbations. Soil Biol Biochem 103:160-170. https://doi.org/10.1016/j.soilbio.2016.08.013 
Deforest $J L$ (2009) The influence of time, storage temperature, and substrate age on potential soil enzyme activity in acidic forest soils using MUBlinked substrates and L-DOPA. Soil Biol Biochem 41(6):1180-1186. https://doi.org/10.1016/j.soilbio.2009.02.029

Edgar RC (2013) UPARSE: highly accurate OTU sequences from microbial amplicon reads. Nat Methods 10(10):996-998. https://doi.org/10.1038/ nmeth.2604

Edgar RC, Haas BJ, Clemente JC, Quince C, Knight R (2011) UCHIME improves sensitivity and speed of chimera detection. Bioinformatics 27(16):21942200. https://doi.org/10.1093/bioinformatics/btr381

Edwards KA, McCulloch J, Kershaw GP, Jefferies RL (2006) Soil microbial and nutrient dynamics in a wet Arctic sedge meadow in late winter and early spring. Soil Biol Biochem 38(9):2843-2851. https://doi.org/10. 1016/j.soilbio.2006.04.042

Elliott ET (1986) Aggregate structure and carbon, nitrogen, and phosphorus in native and cultivated soils. Soil Sci Soc Am J 50(3):627-633. https://doi. org/10.2136/sssaj1986.03615995005000030017x

Ernakovich JG, Wallenstein MD (2015) Permafrost microbial community traits and functional diversity indicate low activity at in situ thaw temperatures. Soil Biol Biochem 87:78-89. https://doi.org/10.1016/j.soilbio.2015. 04.009

Feng X, Nielsen LL, Simpson MJ (2007) Responses of soil organic matter and microorganisms to freeze-thaw cycles. Soil Biol Biochem 39(8):20272037. https://doi.org/10.1016/j.soilbio.2007.03.003

Fierer N, Bradford MA, Jackson RB (2007) Toward an ecological classification of soil bacteria. Ecology 88(6):1354-1364. https://doi.org/10.1890/05-1839

Fierer N, Lauber CL, Ramirez KS, Zaneveld J, Bradford MA, Knight R (2012) Comparative metagenomic, phylogenetic and physiological analyses of soil microbial communities across nitrogen gradients. ISME J 6(5):10071017. https://doi.org/10.1038/ismej.2011.159

Fitzhugh RD, Driscoll CT, Groffman PM, Tierney GL, Fahey TJ, Hardy JP (2001) Effects of soil freezing disturbance on soil solution nitrogen, phosphorus, and carbon chemistry in a northern hardwood ecosystem. Biogeochemistry 56(2):215-238. https://doi.org/10.1023/a:1013076609950

George SF, Fierer N, Levy JS, Adams B (2021) Antarctic water tracks: microbial community responses to variation in soil moisture, $\mathrm{pH}$, and salinity. Front Microbiol 12:616730. https://doi.org/10.3389/fmicb.2021.616730

German DP, Weintraub MN, Grandy AS, Lauber CL, Rinkes ZL, Allison SD (2011) Optimization of hydrolytic and oxidative enzyme methods for ecosystem studies. Soil Biol Biochem 43(7):1387-1397. https://doi.org/ 10.1016/j.soilbio.2011.03.017

Goldfarb KC, Karaoz U, Hanson CA, Santee CA, Bradford MA, Treseder KK, Wallenstein MD, Brodie EL (2011) Differential growth responses of soil bacterial taxa to carbon substrates of varying chemical recalcitrance. Front Microbiol 2(94):00094. https://doi.org/10.3389/fmicb.2011.00094

Grogan P, Michelsen A, Ambus P, Jonasson S (2004) Freeze-thaw regime effects on carbon and nitrogen dynamics in sub-arctic heath tundra mesocosms. Soil Biol Biochem 36(4):641-654. https://doi.org/10.1016/j. soilbio.2003.12.007

Guhr A, Borken W, Spohn M, Matzner E (2015) Redistribution of soil water by a saprotrophic fungus enhances carbon mineralization. Proc Natl Acad Sci USA 112(47):14647-14651. https://doi.org/10.1073/pnas.15144 35112

Haei M, Rousk J, Ilstedt U, Öquist M, Bååth E, Laudon H (2011) Effects of soil frost on growth, composition and respiration of the soil microbial decomposer community. Soil Biol Biochem 43(10):2069-2077. https:// doi.org/10.1016/j.soilbio.2011.06.005

Herrmann A, Witter E (2002) Sources of C and N contributing to the flush in mineralization upon freeze-thaw cycles in soils. Soil Biol Biochem 34(10):1495-1505. https://doi.org/10.1016/s0038-0717(02)00121-9

Jansson JK, Hofmockel KS (2020) Soil microbiomes and climate change. Nat Rev Microbiol 18(1):35-46. https://doi.org/10.1038/s41579-019-0265-7

Jefferies RL, Walker NA, Edwards KA, Dainty J (2010) Is the decline of soil microbial biomass in late winter coupled to changes in the physical state of cold soils? Soil Biol Biochem 42(2):129-135. https://doi.org/10.1016/j. soilbio.2009.10.008

Jiang N, Juan Y, Tian L, Chen X, Sun W, Chen L (2018) Modification of the composition of dissolved nitrogen forms, nitrogen transformation processes, and diversity of bacterial communities by freeze-thaw events in temperate soils. Pedobiologia 71:41-49. https://doi.org/10.1016/j. pedobi.2018.08.004
Joergensen RG (1996) The fumigation-extraction method to estimate soil microbial biomass: Calibration of the $k_{\mathrm{EC}}$ value. Soil Biol Biochem 28(1):25-31. https://doi.org/10.1016/0038-0717(95)00102-6

Koponen HT, Jaakkola T, Keinänen-Toivola MM, Kaipainen S, Tuomainen J, Servomaa K, Martikainen PJ (2006) Microbial communities, biomass, and activities in soils as affected by freeze thaw cycles. Soil Biol Biochem 38(7):1861-1871. https://doi.org/10.1016/j.soilbio.2005.12.010

Kvaernø SH, Øygarden L (2006) The influence of freeze-thaw cycles and soil moisture on aggregate stability of three soils in Norway. Catena 67(3):175-182. https://doi.org/10.1016/j.catena.2006.03.011

Larsen KS, Jonasson S, Michelsen A (2002) Repeated freeze-thaw cycles and their effects on biological processes in two arctic ecosystem types. Appl Soil Ecol 21(3):187-195. https://doi.org/10.1016/s0929-1393(02) 00093-8

Leff JW, Wieder WR, Taylor PG, Townsend AR, Nemergut DR, Grandy AS, Cleveland CC (2012) Experimental litterfall manipulation drives large and rapid changes in soil carbon cycling in a wet tropical forest. Global Change Biol 18(9):2969-2979. https://doi.org/10.1111/j.1365-2486.2012 02749.x

Leff JW, Jones SE, Prober SM, Barberán A, Borer ET, Firn JL, Harpole WS, Hobbie SE, Hofmockel KS, Knops JMH, McCulley RL, Pierre KL, Risch AC, Seabloom EW, Schüetz M, Steenbock C, Stevens CJ, Fierer N (2015) Consistent responses of soil microbial communities to elevated nutrient inputs in grasslands across the globe. Proc Natl Acad Sci USA 112(35):1096710972. https://doi.org/10.1073/pnas.1508382112

Li H, Zhang Y, Yang S, Wang Z, Feng X, Liu H, Jiang Y (2019) Variations in soil bacterial taxonomic profiles and putative functions in response to straw incorporation combined with $\mathrm{N}$ fertilization during the maize growing season. Agr Ecosyst Environ 283:106578. https://doi.org/10. 1016/j.agee.2019.106578

Lipson DA, Schmidt SK, Monson RK (2000) Carbon availability and temperature control the post-snowmelt decline in alpine soil microbial biomass. Soil Biol Biochem 32(4):441-448. https://doi.org/10.1016/s0038-0717(99) 00068-1

Liu M, Feng F, Cai T, Tang S (2020) Soil microbial community response differently to the frequency and strength of freeze-thaw events in a Larix gmelinii forest in the Daxing'an Mountains, China. Front Microbiol 11:01164. https://doi.org/10.3389/fmicb.2020.01164

Louca S, Parfrey LW, Doebeli M (2016) Decoupling function and taxonomy in the global ocean microbiome. Science 353(6305):1272-1277. https:// doi.org/10.1126/science.aaf4507

Mikan CJ, Schimel JP, Doyle AP (2002) Temperature controls of microbial respiration in arctic tundra soils above and below freezing. Soil Biol Biochem 34(11):1785-1795. https://doi.org/10.1016/S0038-0717(02)00168-2

Monteux S, Weedon JT, Blume-Werry G, Gavazov K, Jassey VEJ, Johansson M, Keuper F, Olid C, Dorrepaal E (2018) Long-term in situ permafrost thaw effects on bacterial communities and potential aerobic respiration. ISME J 12(9):2129-2141. https://doi.org/10.1038/s41396-018-0176-z

Moorhead DL, Sinsabaugh RL (2006) A theoretical model of litter decay and microbial interaction. Ecol Monogr 76(2):151-174. https://doi.org/10. 1890/0012-9615(2006)076[0151:atmold]2.0.co;2

Mooshammer M, Hofhansl F, Frank AH, Wanek W, Hämmerle I, Leitner S, Schnecker J, Wild B, Watzka M, Keiblinger KM, Zechmeister-Boltenstern S, Richter A (2017) Decoupling of microbial carbon, nitrogen, and phosphorus cycling in response to extreme temperature events. Sci Adv 3(5):e1602781. https://doi.org/10.1126/sciadv.1602781

Murphy J, Riley JP (1962) A modified single solution method for determination of phosphate in natural waters. Anal Chim Acta 27:31-36. https://doi. org/10.1016/S0003-2670(00)88444-5

Muyzer G, Waal ECD, Uitterlinden AG (1993) Profiling of complex microbial populations by denaturing gradient gel electrophoresis analysis of polymerase chain reaction-amplified genes coding for $16 \mathrm{~S}$ rRNA. Appl Environ Microb 59(3):695-700. https://doi.org/10.1128/aem.59.3.695700.1993

Nguyen NH, Song Z, Bates ST, Branco S, Tedersoo L, Menke J, Schilling JS, Kennedy PG (2016) FUNGuild: An open annotation tool for parsing fungal community datasets by ecological guild. Fungal Ecol 20:241-248. https://doi.org/10.1016/j.funeco.2015.06.006

O'Brien SL, Gibbons SM, Owens SM, Hampton-Marcell J, Johnston ER, Jastrow JD, Gilbert JA, Meyer F, Antonopoulos DA (2016) Spatial scale drives 
patterns in soil bacterial diversity. Environ Microbiol 18(6):2039-2051. https://doi.org/10.1111/1462-2920.13231

Olsen SR, Cole CV, Watanabe FS, Dean LA (1954) Estimation of available phosphorus in soils by extraction with sodium bicarbonate. USDA Circular 939:1-19

Öquist MG, Sparrman T, Klemedtsson L, Drotz SH, Grip H, Schleucher J, Nilsson M (2009) Water availability controls microbial temperature responses in frozen soil $\mathrm{CO}_{2}$ production. Global Change Biol 15(11):2715-2722. https://doi.org/10.1111/j.1365-2486.2009.01898.x

Peng X, Wang W (2016) Stoichiometry of soil extracellular enzyme activity along a climatic transect in temperate grasslands of northern China. Soil Biol Biochem 98:74-84. https://doi.org/10.1016/j.soilbio.2016.04. 008

Perez-Mon C, Frey B, Frossard A (2020) Functional and structural responses of arctic and alpine soil prokaryotic and fungal communities under freezethaw cycles of different frequencies. Front Microbiol 11:00982. https:// doi.org/10.3389/fmicb.2020.00982

Quast C, Pruesse E, Yilmaz P, Gerken J, Schweer T, Yarza P, Peplies J, Glöckner FO (2013) The SILVA ribosomal RNA gene database project: improved data processing and web-based tools. Nucleic Acids Res 41(D1):590-596. https://doi.org/10.1093/nar/gks1219

Ren J, Song C, Hou A, Song Y, Zhu X, Cagle GA (2018) Shifts in soil bacterial and archaeal communities during freeze-thaw cycles in a seasonal frozen marsh, Northeast China. Sci Total Environ 625:782-791. https://doi.org/ 10.1016/j.scitotenv.2017.12.309

Risk N, Snider D, Wagner-Riddle C (2013) Mechanisms leading to enhanced soil nitrous oxide fluxes induced by freeze-thaw cycles. Can J Soil Sci 93(4):401-414. https://doi.org/10.4141/cjss2012-071

Rivkina EM, Friedmann El, McKay CP, Gilichinsky DA (2000) Metabolic activity of permafrost bacteria below the freezing point. Appl Environ Microb 66(8):3230-3233. https://doi.org/10.1128/AEM.66.8.3230-3233.2000

Saiya-Cork KR, Sinsabaugh RL, Zak DR (2002) The effects of long term nitrogen deposition on extracellular enzyme activity in an Acer saccharum forest soil. Soil Biol Biochem 34(9):1309-1315. https://doi.org/10.1016/s00380717(02)00074-3

Sawicka JE, Robador A, Hubert C, Jørgensen BB, Brüchert V (2010) Effects of freeze-thaw cycles on anaerobic microbial processes in an Arctic intertidal mud flat. ISME J 4(4):585-594. https://doi.org/10.1038/ismej. 2009.140

Schimel JP, Mikan C (2005) Changing microbial substrate use in Arctic tundra soils through a freeze-thaw cycle. Soil Biol Biochem 37(8):1411-1418. https://doi.org/10.1016/j.soilbio.2004.12.011

Schimel JP, Weintraub MN (2003) The implications of exoenzyme activity on microbial carbon and nitrogen limitation in soil: a theoretical model. Soil Biol Biochem 35(4):549-563. https://doi.org/10.1016/s00380717(03)00015-4

Scott JT, Condron LM (2003) Dynamics and availability of phosphorus in the rhizosphere of a temperate silvopastoral system. Biol Fert Soils 39(2):65-73. https://doi.org/10.1007/s00374-003-0678-2

Sinsabaugh RL, Hill BH, Shah JJF (2009) Ecoenzymatic stoichiometry of microbial organic nutrient acquisition in soil and sediment. Nature 462(7274):795-798. https://doi.org/10.1038/nature08632

Sjursen $\mathrm{H}$, Michelsen A, Holmstrup M (2005) Effects of freeze-thaw cycles on microarthropods and nutrient availability in a sub-Arctic soil. Appl Soil Ecol 28(1):79-93. https://doi.org/10.1016/j.apsoil.2004.06.003

Song Y, Zou Y, Wang G, Yu X (2017) Altered soil carbon and nitrogen cycles due to the freeze-thaw effect: A meta-analysis. Soil Biol Biochem 109:35-49. https://doi.org/10.1016/j.soilbio.2017.01.020

Sorensen PO, Finzi AC, Giasson M-A, Reinmann AB, Sanders-DeMott R, Templer PH (2018) Winter soil freeze-thaw cycles lead to reductions in soil microbial biomass and activity not compensated for by soil warming. Soil Biol Biochem 116:39-47. https://doi.org/10.1016/j.soilbio.2017.09. 026

Stefan G, Cornelia B, Jörg R, Michael B (2014) Soil water availability strongly alters the community composition of soil protists. Pedobiologia 57(4-6):205-213. https://doi.org/10.1016/j.pedobi.2014.10.001

Su M, Kleineidam K, Schloter M (2010) Influence of different litter quality on the abundance of genes involved in nitrification and denitrification after freezing and thawing of an arable soil. Biol Fert Soils 46(5):537541. https://doi.org/10.1007/s00374-010-0449-9
Sun R, Dsouza M, Gilbert JA, Guo X, Wang D, Guo Z, Ni Y, Chu H (2016) Fungal community composition in soils subjected to long-term chemical fertilization is most influenced by the type of organic matter. Environ Microbiol 18(12):5137-5150. https://doi.org/10.1111/1462-2920.13512

Supramaniam Y, Chong C-W, Silvaraj S, Tan IK-P (2016) Effect of short term variation in temperature and water content on the bacterial community in a tropical soil. Appl Soil Ecol 107:279-289. https://doi.org/10.1016/j. apsoil.2016.07.003

Tierney GL, Fahey TJ, Groffman PM, Hardy JP, Fitzhugh RD, Driscoll CT (2001) Soil freezing alters fine root dynamics in a northern hardwood forest. Biogeochemistry 56(2):175-190. https://doi.org/10.1023/a:1013072519 889

Tikhonova EN, Men'ko EV, Ulanova RV, Li H, Kravchenko IK, (2020) Effect of temperature on the taxonomic structure of soil bacterial communities during litter decomposition. Microbiology 88(6):781-785. https://doi. org/10.1134/s0026261719060195

Treseder KK, Allen EB, Egerton-Warburton LM, Hart MM, Klironomos JN, Maherali $\mathrm{H}$, Tedersoo L (2018) Arbuscular mycorrhizal fungi as mediators of ecosystem responses to nitrogen deposition: A trait-based predictive framework. J Ecol 106(2):480-489. https://doi.org/10.1111/1365-2745. 12919

Turlapati SA, Minocha R, Bhiravarasa PS, Tisa LS, Thomas WK, Minocha SC (2013) Chronic N-amended soils exhibit an altered bacterial community structure in Harvard Forest, MA, USA. FEMS Microbiol Ecol 83(2):478493. https://doi.org/10.1111/1574-6941.12009

van Bochove E, Prévost D, Pelletier F (2000) Effects of freeze-thaw and soil structure on nitrous oxide produced in a clay soil. Soil Sci Soc Am J 64(5):1638-1643. https://doi.org/10.2136/sssaj2000.6451638x

Vimercati L, de Mesquita CPB, Schmidt SK (2020) Limited response of Indigenous microbes to water and nutrient pulses in high-elevation Atacama soils: Implications for the cold-dry limits of life on earth. Microorganisms 8(7):1061. https://doi.org/10.3390/microorganisms8071061

Wang Q, Garrity GM, Tiedje JM, Cole JR (2007) Naïve Bayesian classifier for rapid assignment of rRNA sequences into the new bacterial taxonomy. Appl Environ Microb 73(16):5264-5267. https://doi.org/10.1128/AEM. 00062-07

Wang W, Shu X, Zhang Q, Guénon R (2015) Effects of freeze-thaw cycles on the soil nutrient balances, infiltration, and stability of cyanobacterial soil crusts in northern China. Plant Soil 386(1-2):263-272. https://doi.org/ 10.1007/s11104-014-2263-X

Waring BG, Weintraub SR, Sinsabaugh RL (2014) Ecoenzymatic stoichiometry of microbial nutrient acquisition in tropical soils. Biogeochemistry 117(1):101-113. https://doi.org/10.1007/s10533-013-9849-x

Weidner S, Koller R, Latz E, Kowalchuk G, Bonkowski M, Scheu S, Jousset A (2015) Bacterial diversity amplifies nutrient-based plant-soil feedbacks. Funct Ecol 29(10):1341-1349. https://doi.org/10.1111/1365-2435.12445

Xu YB, Cai ZC (2007) Denitrification characteristics of subtropical soils in China affected by soil parent material and land use. Eur J Soil Sci 58(6):12931303. https://doi.org/10.1111/j.1365-2389.2007.00923.x

Yanai Y, Toyota K, Okazaki M (2004) Effects of successive soil freeze-thaw cycles on soil microbial biomass and organic matter decomposition potential of soils. Soil Sci Plant Nutr 50(6):821-829. https://doi.org/10.1080/00380 768.2004 .10408542

Yang Y, Dou Y, Huang Y, An S (2017) Links between soil fungal diversity and plant and soil properties on the Loess Plateau. Front Microbiol 8:02198. https://doi.org/10.3389/fmicb.2017.02198

Yang KJ, Peng CH, Penuelas J, Kardol P, Li ZJ, Zhang L, Ni XY, Yue K, Tan B, Yin R, Xu ZF (2019) Immediate and carry-over effects of increased soil frost on soil respiration and microbial activity in a spruce forest. Soil Biol Biochem 135:51-59. https://doi.org/10.1016/.jsoilbio.2019.04.012

Yang W, Cai A, Wang J, Luo Y, Cheng X, An S (2020) Exotic Spartina alterniflora Loisel. invasion significantly shifts soil bacterial communities with the successional gradient of saltmarsh in eastern China. Plant Soil 449(1):97-115. https://doi.org/10.1007/s11104-020-04470-y

Yergeau E, Kowalchuk GA (2008) Responses of Antarctic soil microbial communities and associated functions to temperature and freeze-thaw cycle frequency. Environ Microbiol 10(9):2223-2235. https://doi.org/10. 1111/j.1462-2920.2008.01644.x

Yu X, Zhang Y, Zhao H, Lu X, Wang G (2010) Freeze-thaw effects on sorption/ desorption of dissolved organic carbon in wetland soils. Chinese Geogr Sci 20(3):209-217. https://doi.org/10.1007/s11769-010-0209-7 
Zeng J, Liu X, Song L, Lin X, Zhang H, Shen C, Chu H (2016) Nitrogen fertilization directly affects soil bacterial diversity and indirectly affects bacterial community composition. Soil Biol Biochem 92:41-49. https://doi.org/ 10.1016/j.soilbio.2015.09.018

Zgadzaj R, Garrido-Oter R, Jensen DB, Koprivova A, Schulze-Lefert P, Radutoiu $\mathrm{S}$ (2016) Root nodule symbiosis in Lotus japonicus drives the establishment of distinctive rhizosphere, root, and nodule bacterial communities. Proc Natl Acad Sci USA 113(49):7996-8005. https://doi.org/10 1073/pnas.1616564113

Zhang H, Tang J, Liang S (2017) Effects of snow cover plus straw mulching on microorganisms in paddy soil during winter. Appl Soil Ecol 119:339344. https://doi.org/10.1016/j.apsoil.2017.05.023

Zhou W, Chen H, Zhou L, Lewis BJ, Ye Y, Tian J, Li G, Dai L (2011) Effect of freezing-thawing on nitrogen mineralization in vegetation soils of four landscape zones of Changbai Mountain. Ann Forest Sci 68(5):943-951. https://doi.org/10.1007/s13595-011-0100-4

Zhou J, Jiang X, Wei D, Zhao B, Ma M, Chen S, Cao F, Shen D, Guan D, Li J (2017) Consistent effects of nitrogen fertilization on soil bacterial communities in black soils for two crop seasons in China. Sci Rep 7(1):3267. https:// doi.org/10.1038/s41598-017-03539-6

\section{Publisher's Note}

Springer Nature remains neutral with regard to jurisdictional claims in published maps and institutional affiliations.

\section{Submit your manuscript to a SpringerOpen ${ }^{\circ}$ journal and benefit from:}

- Convenient online submission

- Rigorous peer review

- Open access: articles freely available online

- High visibility within the field

- Retaining the copyright to your article

Submit your next manuscript at $\boldsymbol{\nabla}$ springeropen.com 